\title{
Review Article \\ Roles of Zinc Signaling in the Immune System
}

\author{
Shintaro Hojyo ${ }^{1}$ and Toshiyuki Fukada ${ }^{2}$ \\ ${ }^{1}$ Osteoimmunology, Deutsches Rheuma-Forschungszentrum, Berlin, Germany \\ ${ }^{2}$ Faculty of Pharmaceutical Sciences, Tokushima Bunri University, Tokushima, Japan \\ Correspondence should be addressed to Toshiyuki Fukada; fukada@ph.bunri-u.ac.jp
}

Received 1 July 2016; Accepted 11 August 2016

Academic Editor: Manoj K. Mishra

Copyright (C) 2016 S. Hojyo and T. Fukada. This is an open access article distributed under the Creative Commons Attribution License, which permits unrestricted use, distribution, and reproduction in any medium, provided the original work is properly cited.

Zinc $(\mathrm{Zn})$ is an essential micronutrient for basic cell activities such as cell growth, differentiation, and survival. Zn deficiency depresses both innate and adaptive immune responses. However, the precise physiological mechanisms of the Zn-mediated regulation of the immune system have been largely unclear. Zn homeostasis is tightly controlled by the coordinated activity of $\mathrm{Zn}$ transporters and metallothioneins, which regulate the transport, distribution, and storage of $\mathrm{Zn}$. There is growing evidence that $\mathrm{Zn}$ behaves like a signaling molecule, facilitating the transduction of a variety of signaling cascades in response to extracellular stimuli. In this review, we highlight the emerging functional roles of $\mathrm{Zn}$ and $\mathrm{Zn}$ transporters in immunity, focusing on how crosstalk between $\mathrm{Zn}$ and immune-related signaling guides the normal development and function of immune cells.

\section{Introduction}

In the 1960s, Prasad and his colleagues reported that zinc (Zn) plays indispensable roles in such diverse cellular events as cell proliferation, differentiation, and survival in humans [1]. In the past decade, studies in animal models have provided considerable knowledge about the molecular principles of Zn's function in the immune system, including new insights into how a single nutritional deficiency can alter immunecell homeostasis and functions in both innate and adaptive immunity. Zn's physiological importance is supported by recent in silico studies showing that the proteins encoded by approximately $10 \%$ of entire genome in Homo sapiens can potentially bind $\mathrm{Zn}$ through $\mathrm{Zn}$-finger motifs, RING finger domains, LIM domains, and PHD domains [2], all of which are involved in basic cellular activities [3]. In the present era, approximately two billion people in developing countries suffer from $\mathrm{Zn}$ deficiency $(\mathrm{ZnD})$, mainly due to malnutrition and manifest clinical characteristics of growth retardation and compromised immune systems $[1,4]$. $\mathrm{ZnD}$ induces thymic atrophy and lymphopenia and depresses both innate and adaptive immune responses: it impairs phagocytosis, intracellular killing activity, and cytokine production by macrophages; host defense by neutrophils and natural killer cells; and the proliferation, cytokine production, and antibody secretion of T and B cells [5]. These outcomes, which appear to be mostly rooted in the dysregulation of basic cellular functions such as DNA replication, RNA transcription, and cell activation, proliferation, differentiation, and survival [6-11], result in an increased susceptibility to a wide range of infectious agents and a longer duration of infection $[1,5]$.

$\mathrm{Zn}$ homeostasis is tightly controlled by $\mathrm{Zn}$ transporters and metallothioneins [12]. Zn acts as a cofactor for proteins and affects the structural and catalytic functions of enzymes and transcription factors [12]. In addition to recent mechanistic investigations into Zn's functions, other recent studies using chemical or gene-targeting approaches have revealed Zn's role as a second messenger, similar to that of cyclic adenosine monophosphate (cAMP) and calcium, in $\mathrm{Zn}$ signaling axes mediated by specific channels or $\mathrm{Zn}$ transporters [12].

In this review, we describe recent discoveries about the role of $\mathrm{Zn}$ signaling in the immune system and along specific $\mathrm{Zn}$ transporter axes. We will particularly focus on the physiological importance of $\mathrm{Zn}$ signaling in dendritic cells (DCs), T cells, and B cells, major populations that are required for crosstalk between the innate and adaptive immune systems. Ongoing research in this field will improve our understanding of the physiological significance of this vital trace element. 


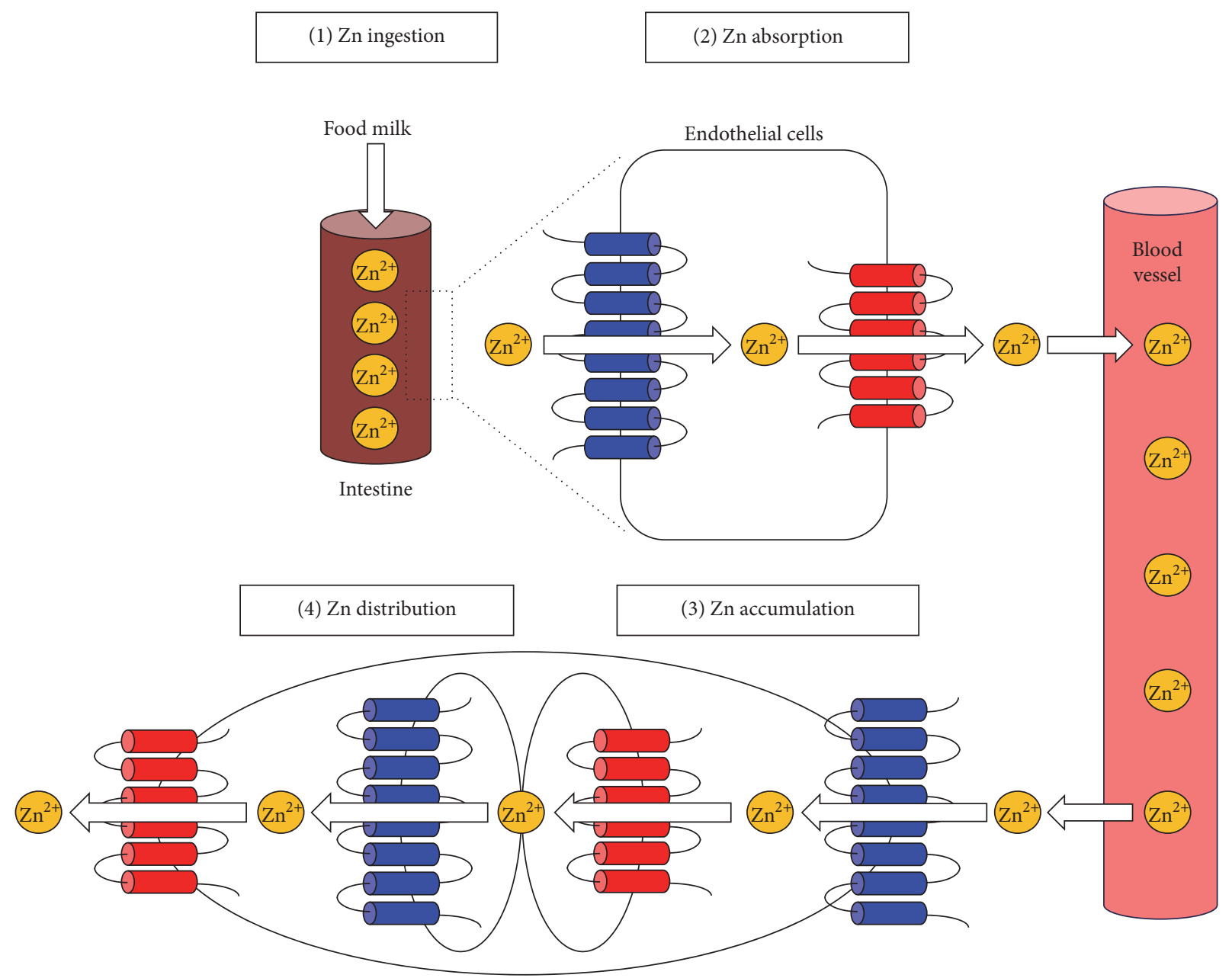

FIGURE 1: Zn transporters control Zn homeostasis. (1) Zn is ingested from the diet (or from breast milk in infants). (2) Zn is absorbed by intestinal $\mathrm{Zn}$ transporters and is released into the bloodstream. (3) $\mathrm{Zn}$ is taken up into peripheral cells by $\mathrm{Zn}$ transporters located on the plasma membrane. (4) $\mathrm{Zn}$ is distributed within the cell by intracellular $\mathrm{Zn}$ transporters. Each step is important for maintaining intracellular Zn levels. Disrupting Zn uptake results in ZnD and subsequent pathogenesis. ZIP (blue) and ZnT (red) transporters are indicated.

\section{Physiological Roles of Zn Transporters in Zn Homeostasis}

$\mathrm{Zn}$ is the second most abundant metal in the human body, with 2-4 grams distributed throughout the whole body. Zn is generally taken in through food or breast milk, is absorbed via several intestinal $\mathrm{Zn}$ transporters, and is released into the bloodstream (Figure 1). Circulating $\mathrm{Zn}$ is taken up into cells and distributed within the cell (Figure 1). At each step, $\mathrm{Zn}$ transporters and metallothioneins play coordinated roles in the transport, distribution, and homeostatic maintenance of $\mathrm{Zn}$ (Figure 2) [12]. Based on their predicted membrane topology, $\mathrm{Zn}$ transporters are divided into two major families, SLC39s/ZIPs and SLC30s/ZnTs, which mediate the inward and outward transport of $\mathrm{Zn}$ through cell-surface membranes and intracellular organelles (Figure 2) [13].

The ZIP family, which consists of 14 members containing eight putative transmembrane domains, elevates intracellular cytoplasmic $\mathrm{Zn}$ levels by eliciting the influx of $\mathrm{Zn}$ from the extracellular space or from intracellular organelles [12].
No ZIP crystal structure has been determined, but ZIPs are postulated to transport $\mathrm{Zn}$ by diffusion, symporters, or a secondary active transport system but not via an ATPdependent mechanism.

Accumulated evidence from genetic approaches has demonstrated specific physiological roles of $\mathrm{Zn}$ transporters in mice and humans (Table 1) [12]. A single ablation of the ZIP1, ZIP2, or ZIP3 allele or a double ablation of ZIP1 and ZIP2 in mice leads to abnormal embryonic development in the $\mathrm{ZnD}$ environment of the mother [14-16]. ZIP4, the most intensively studied Zn transporter in human genetics, serves as a first gate for absorbing $\mathrm{Zn}$ into the body through the apical membrane of enterocytes [17]. Loss-of-function mutations in ZIP4 lead to acrodermatitis enteropathica (AE; OMIM 201100), a rare, pseudodominant, lethal genetic disorder characterized by severe $\mathrm{ZnD}$ symptoms such as periorificial and acral dermatitis, alopecia, and diarrhea in infants [17-20]. Supplementing with at least 1-2 mg Zn per $\mathrm{kg}$ of body weight per day dramatically improves the health and saves the lives of these patients, who would otherwise 


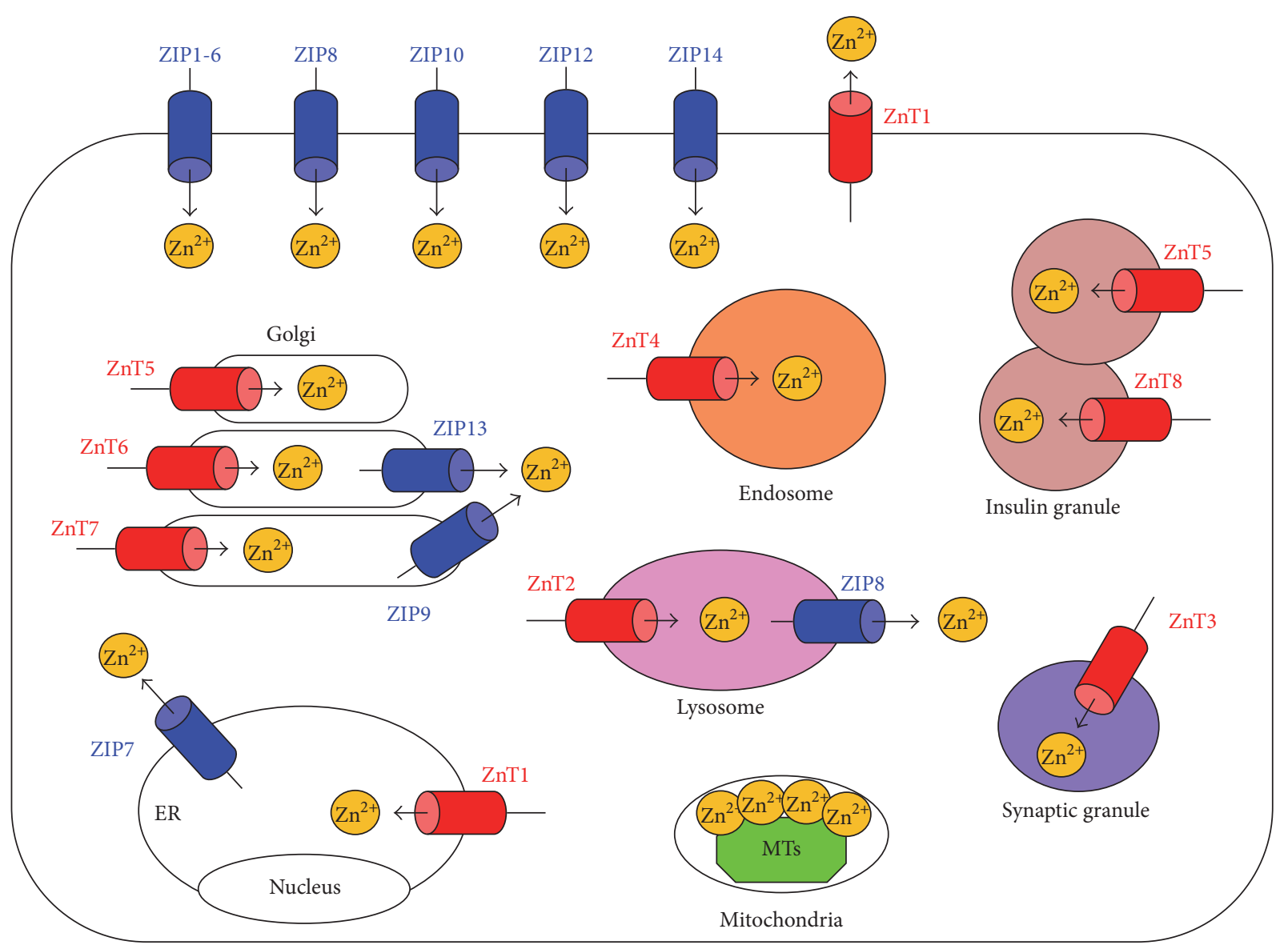

FIGURE 2: Subcellular localization of Zn transporters and metallothioneins (MTs). The localization of ZIP (blue) and ZnT (red) transporters is determined by the cell type, developmental process, and Zn status. ZIP transporters elevate the intracellular cytoplasmic Zn level by eliciting the influx of $\mathrm{Zn}$ from the extracellular space or from intracellular organelles. ZnT transporters reduce the intracellular cytoplasmic Zn level by exporting $\mathrm{Zn}$ from the cytosol to the extracellular space or into intracellular organelles or vesicles. MTs (green) contribute to Zn storage. Arrows indicate the predicted direction of $\mathrm{Zn}$ mobilization. ER: endoplasmic reticulum.

die within 2 years $[17,19]$. In mice, targeted disruption of the ZIP4 gene impairs early embryonic development, since ZIP4 is thought to transport $\mathrm{Zn}$ into the embryo via the visceral yolk sac and later by the uptake of dietary $\mathrm{Zn}$ through the intestine [21]. Furthermore, mice with conditional ZIP4 ablation in enterocytes exhibit dramatic wasting and death unless they receive additional dietary $\mathrm{Zn}$ through nursing or supplementation [22]. These mice have reduced labile $\mathrm{Zn}$ and abnormal gene expression in Paneth cells, leading to an abnormal stem-cell niche in the crypts and subsequent disorganization of the absorptive epithelium. Loss-of-function ZIP5 mutations are associated with autosomal dominant nonsyndromic high myopia [23]. ZIP8hypomorphic mice are embryonically lethal due to abnormal hematopoiesis and organ morphogenesis [24]. ZIP8 is also associated with human and murine osteoarthritis, in which an influx of $\mathrm{Zn}$ into cartilage chondrocytes elevates the expression of matrix-degrading enzymes [25]. Most recently, it has been reported that a nonsynonymous variant in ZIP8 is associated with schizophrenia [26]. A lack of ZIP10 impairs B-cell development and function in mice $[27,28]$. Targeted ZIP12 disruption attenuates the development of pulmonary hypertension in rats in a hypoxic atmosphere [29]. ZIP13deficient mice have abnormal systemic and bone growth with characteristics reminiscent of human Ehlers-Danlos syndrome (EDS), a group of recessive genetic disorders that affect connective tissue development, and of Osteogenesis Imperfecta, formally named as Spondylocheirodysplastic Ehlers-Danlos syndrome (SCD-EDS, OMIM 612350) [3035]. ZIP14-deficient mice have impairments in systemic growth, bone metabolism, and gluconeogenesis [35], impaired liver regeneration (after partial hepatectomy) [36], decreased insulin signaling and hypertrophied adipocytes, and increased adipose cytokine production and plasma leptin [37]. In addition, it has been recently reported that the homozygous loss-of-function mutations of ZIP14 cause progressive parkinsonism-dystonia and neurodegeneration with hypermanganesemia in childhood [38].

The ZnT family, which consists of 10 members containing six transmembrane domains [12], reduces intracellular cytoplasmic $\mathrm{Zn}$ levels by exporting $\mathrm{Zn}$ from the cytosol to the extracellular space or into intracellular organelles or vesicles. Mice with a targeted disruption of ZnT1 exhibit embryonic lethality [39]. In mice, a targeted disruption or mutation 
TABLE 1: Zn transporters in physiology and pathophysiology.

\begin{tabular}{|c|c|c|c|c|}
\hline Gene symbol & Protein name & Mutation type & Phenotype and disorder & Reference \\
\hline SLC39A1 & ZIP1 & $\mathrm{KO}$ & Abnormal embryonic development & [15] \\
\hline SLC39A2 & ZIP2 & $\mathrm{KO}$ & Abnormal embryonic development & {$[16]$} \\
\hline SLC39A3 $^{* 1}$ & ZIP3 & $\mathrm{KO}$ & Abnormal embryonic and T-cell development & {$[14]$} \\
\hline \multirow{2}{*}{ SLC39A $4^{* 2}$} & \multirow[t]{2}{*}{ ZIP4 } & $\mathrm{KO}$ & Embryonic lethality & \multirow[t]{2}{*}{$18,20-22,60$} \\
\hline & & Mutation & $\mathrm{AE}$ & \\
\hline SLC39A5 & ZIP5 & Mutation & Autosomal dominant nonsyndromic high myopia & {$[23]$} \\
\hline \multirow{4}{*}{ SLC39A $8^{* 3}$} & \multirow{4}{*}{ ZIP8 } & Hypomorphic & Impaired multiple-organ organogenesis and hematopoiesis & \multirow{4}{*}[24-26,61]{} \\
\hline & & mutation & Abnormal innate immune function & \\
\hline & & $\mathrm{KO}$ & Osteoarthritis & \\
\hline & & SNP & Schizophrenia & \\
\hline \multirow{2}{*}{ SLC39A10*4 } & \multirow{2}{*}{ ZIP10 } & \multirow{2}{*}{$\mathrm{KO}$} & Abnormal early B-cell development & \multirow{2}{*}[27,28]{} \\
\hline & & & Impaired humoral immune response & \\
\hline SLC39A12 & ZIP12 & $\mathrm{KO}$ & Attenuation of pulmonary hypertension in a hypoxic atmosphere & {$[29]$} \\
\hline \multirow{2}{*}{ SLC39A13 } & \multirow{2}{*}{ ZIP13 } & $\mathrm{KO}$ & Connective tissue dysplasia & \multirow{2}{*}[34,62]{} \\
\hline & & Mutation & SCD-EDS & \\
\hline
\end{tabular}

Growth retardation and impaired gluconeogenesis

Impaired hepatocyte proliferation during liver regeneration after

KO hepatectomy

SLC39A14 ZIP14 Decreased insulin signaling, hypertrophied adipocytes, and

increased adipose cytokine production and plasma leptin

Mutation Parkinsonism-dystonia and neurodegeneration with hypermanganesemia in childhood

\begin{tabular}{|c|c|c|c|c|}
\hline \multirow{3}{*}{ SLC30A1 } & \multirow{3}{*}{$\mathrm{ZnT1}$} & \\
\hline & & $\mathrm{KO}$ & Embryonic lethality & {$[39,63]$} \\
\hline & & \multicolumn{3}{|c|}{ Abnormal vulva formation } \\
\hline SLC30A2 & $\mathrm{ZnT} 2$ & $\begin{array}{l}\text { Mutation } \\
\mathrm{KO}\end{array}$ & Low $\mathrm{Zn}$ in milk & [40-43] \\
\hline SLC30A3 & ZnT3 & KO & $\begin{array}{l}\text { Prone to seizures } \\
\text { Alzheimer's disease-like abnormalities }\end{array}$ & {$[45,64]$} \\
\hline SLC30A4 & $\mathrm{ZnT} 4$ & Mutation & $\begin{array}{l}\text { Lethal milk: } \operatorname{lm} \\
\text { Low Zn in milk } \\
\end{array}$ & {$[46]$} \\
\hline \multirow[t]{2}{*}{ SLC30A5 } & \multirow[t]{2}{*}{ ZnT5 } & \multirow[t]{2}{*}{$\mathrm{KO}$} & $\begin{array}{l}\text { Growth retardation, osteopenia, hypodontia, and male-specific } \\
\text { cardiac death }\end{array}$ & \multirow[t]{2}{*}[47,48]{} \\
\hline & & & Impaired mast-cell functions & \\
\hline \multirow[b]{2}{*}{ SLC30A7 } & \multirow[b]{2}{*}{ ZnT7 } & \multirow[b]{2}{*}{$\mathrm{KO}$} & Reduced body fat accumulation & \multirow[b]{2}{*}[49,50]{} \\
\hline & & & $\begin{array}{l}\text { Insulin resistance, glucose intolerance, and hyperglycemia on a } \\
\text { high-fat diet }\end{array}$ & \\
\hline \multirow{2}{*}{ SLC30A8 } & \multirow{2}{*}{ ZnT8 } & KO & Type 2 diabetes mellitus & \multirow{2}{*}[51-56]{} \\
\hline & & SNP & Type 1 and 2 diabetes mellitus & \\
\hline SLC30A10 & ZnT10 & Mutation & $\begin{array}{l}\text { Parkinsonism, dystonia, hypermanganesemia, polycythemia, and } \\
\text { chronic liver disease }\end{array}$ & {$[57-59]$} \\
\hline \multicolumn{5}{|c|}{$\begin{array}{l}{ }^{* 1} \text { Mice with a targeted ZIP3 deletion show lower DP thymocyte counts but increased number of } \mathrm{CD} 4^{+} \mathrm{SP} \text { or } \mathrm{CD} 8^{+} \mathrm{SP} \text { thymocytes under a Zn-limiting } \\
\text { condition. } \\
{ }^{* 2} \text { Patients with ZIP4 mutation (AE) show severe ZnD symptoms characterized by immunodeficiency with thymic atrophy and lymphopenia, and by recurrent } \\
\text { infections. Epidermal LCs, which inhibit ICD triggered by the ATP release from epidermal keratinocytes, are significantly reduced in the lesions of AE patients, } \\
\text { resulting in inflammatory skin manifestations. However, oral Zn supplementation allows LCs to recolonize and improve clinical symptoms in these patients. } \\
{ }^{* 3} \text { Fetal fibroblasts from ZIP8 hypomorphic mice exhibit dysregulated Zn uptake and increased NF- } \kappa \mathrm{B} \text { activation due to insufficient control of I } \kappa \mathrm{B} \text { kinase. } \\
\text { Consistent with this, mice given ZnD dietary intakes develop excessive inflammation to polymicrobial sepsis. } \\
{ }^{* 4} \text { Mice with a targeted disruption of ZIP10 show impaired early B-cell development and antibody response, due to increased caspase activity and decreased } \\
\text { CD45R PTPase activity, respectively. }\end{array}$} \\
\hline
\end{tabular}


of $\mathrm{ZnT} 2$ results in severe $\mathrm{ZnD}$ in nursing pups due to the extremely low $\mathrm{Zn}$ content of breast milk; a genetic mutation is known to cause the same symptoms in humans [40-43]. ZnT3 localizes to presynaptic vesicles, which are required for extracellular signal-regulated kinase (ERK) activation and hippocampus-dependent memory [44]. A targeted ZnT3 disruption causes memory deficits with Alzheimer's diseaselike abnormalities in mice [45]. Similar to ZnT2-deficient mice, the milk of mice with a loss-of-function mutation in $\mathrm{ZnT4}$ (lethal milk mutant) is deficient in $\mathrm{Zn}$, resulting in postnatal lethality [46]. ZnT5-deficient mice exhibit severe osteopenia, sudden death from bradyarrhythmia in males in their reproductive period [47], and impaired delayedtype allergic responses mediated by mast cells [48]. ZnT7deficient mice show stunted growth due to a decrease in body fat accumulation [49]. In addition, ZnT7-deficient males are resistant to insulin and become hyperglycemic and glucose intolerant on a high-fat diet [50]. The ZnT8 transporter is associated with both type 1 [51] and type 2 diabetes mellitus [52]. ZnT8-deficient mice have impaired insulin secretion and crystal formation in diabetes mellitus [53-55] and rapidly clear insulin from the liver [56]. ZnT10 mutations cause parkinsonism and dystonia with hypermanganesemia, polycythemia, and chronic liver disease [57-59].

\section{Zn-Signal Axes (Zn-Zn Transporter Signaling)}

Neurons respond to exocytotic stimuli by releasing vesicular $\mathrm{Zn}$ into the surrounding milieu, where it is probably taken up into adjacent postsynaptic neurons and glial cells via $\mathrm{Zn}$ permeable channels [65-68]. Thus, $\mathrm{Zn}$ acts as a neurotransmitter [69-71]. Zn also mimics the actions of hormones, growth factors, and cytokines [72] and regulates their functions by changing their structures via direct binding $[73,74]$. These data suggest that $\mathrm{Zn}$ not only acts as an accessory factor for the function of various cellular components but also behaves as a signaling molecule, like calcium and cAMP [75, 76]. In fact, $\mathrm{Zn}$ acts through $\mathrm{Zn}$ channels and transporters to regulate a variety of signaling cascades mediated by hormone and growth factor receptors [77], cytokine receptors [28, 78, 79], toll-like receptors (TLRs) [61, 80], and antigen receptors $[27,48]$, so called "Zn signaling" [75].

Zn's behavior as a second messenger has been clearly observed in some cell types. For example, mast cells, which induce allergic responses, express a surface Fc epsilon receptor I (FceRI) specific for IgE binding. Upon sensing an antigen through IgE-FceRI engagement, mast cells release intracellular granules containing histamine, lipids, and proteases to initiate an allergic response. Simultaneously, FceRI crosslinking induces a rapid release of intracellular $\mathrm{Zn}$ from the perinuclear area, including the endoplasmic reticulum (ER), in a phenomenon known as the $\mathrm{Zn}$ wave [81]. The $\mathrm{Zn}$ wave depends on calcium influx and mitogen-activated protein kinase (MAPK)/ERK activation and is mediated by the poreforming $\alpha(1)$ subunit of the Cav1.3 ( $\alpha(1 \mathrm{D}))$ L-type calcium channel (LTCC) as a gatekeeper [82]. The LTCC-mediated $\mathrm{Zn}$ wave enhances NF- $\kappa$ B's DNA-binding activity, inducing the gene transcription of inflammatory cytokines (Figure 3).
In fact, LTCC antagonists inhibit the cytokine-mediated, delayed-type allergic reaction in mice without affecting the immediate-type allergic reaction [82]. Furthermore, Nishida et al. demonstrated using ZnT5-deficient mice that ZnT5 in mast cells plays a crucial role in the delayed-type allergic response represented by contact hypersensitivity (Figure 3) [48]. ZnT5 is highly expressed in mast cells and is upregulated by FceRI stimulation. ZnT5-Zn signaling regulates the FceRIinduced translocation of protein kinase $\mathrm{C}$ (PKC) to the plasma membrane, which induces NF- $\kappa$ B activation, leading to the production of interleukin- (IL-) 6 and tumor necrosis factor alpha (TNF- $\alpha$ ) [48]. Thus, Zn signaling via specific $\mathrm{Zn}$ channel and transporter controls FceRI-induced NF- $\kappa \mathrm{B}$ signaling in delayed-type allergic reactions (Figure 3).

Other instances of $\mathrm{Zn}$ signaling via $\mathrm{Zn}$ transporters have been observed. Zn transported by ZIP6 controls embryogenesis by regulating the nuclear translocation of SNAIL (a suppressor of E-cadherin transcription) during the epithelial mesenchymal transition (EMT) in zebrafish [79]. ZIP6-Zn signaling also negatively modulates the TLR-induced activation of DCs during immune responses [80]. The ZIP8-Zn axis negatively regulates NF- $\kappa \mathrm{B}$ activity by downmodulating the $\mathrm{I} \kappa \mathrm{B}$ kinase activity in proinflammatory responses [61]. ZIP10-mediated Zn signaling suppresses caspase activity to promote cell survival in early B-cell development in the bone marrow [28] and regulates the activity of $C D 45 R$ protein tyrosine phosphatase (PTPase) to control the strength of Bcell antigen receptor (BCR) signaling in antibody responses [27]. Most recently, Taylor et al. revealed that ZIP10 forms a heteromeric complex with ZIP6 and controls EMT through inactivation of GSK-3 and downregulation of E-cadherin in a breast cancer cell line and in zebrafish embryos [83]. Zn uptake mediated by ZIP13 and ZIP14 controls systemic growth and bone homeostasis; ZIP13 positively regulates SMAD's nuclear translocation in bone morphogenetic protein/transforming growth factor beta (BMP/TGF- $\beta$ ) signaling [34], and ZIP14 suppresses phosphodiesterase (PDE) activity to maintain cAMP levels in hormone-G-protein coupled receptor (GPCR) signaling [35]. ZIP14-induced Zn signaling also inhibits the protein tyrosine phosphatase $1 \mathrm{~B}$ (PTP1B) activity, thereby increasing c-Met phosphorylation to promote hepatocyte proliferation during liver regeneration [36]. Collectively, these findings indicate that individual $\mathrm{Zn}$ transporters form specific $\mathrm{Zn}$ signaling axes to selectively organize distinct intracellular signaling events.

\section{Roles of $\mathrm{Zn}$ and $\mathrm{Zn}$ Transporters in the Adaptive Immune System}

ZnD's multifaceted effect on the immune system results in a high susceptibility to a variety of infections. Zn supplementation effectively improves immunity on the one hand and efficiently ameliorates chronic dysfunctional inflammatory responses on the other. These findings strongly suggest that $\mathrm{Zn}$ is essential for normal immune-cell homeostasis and function. There is already an excellent body of literature about Zn's roles in specific innate cell types, such as monocytes/macrophages and natural killer cells [84, 85], 


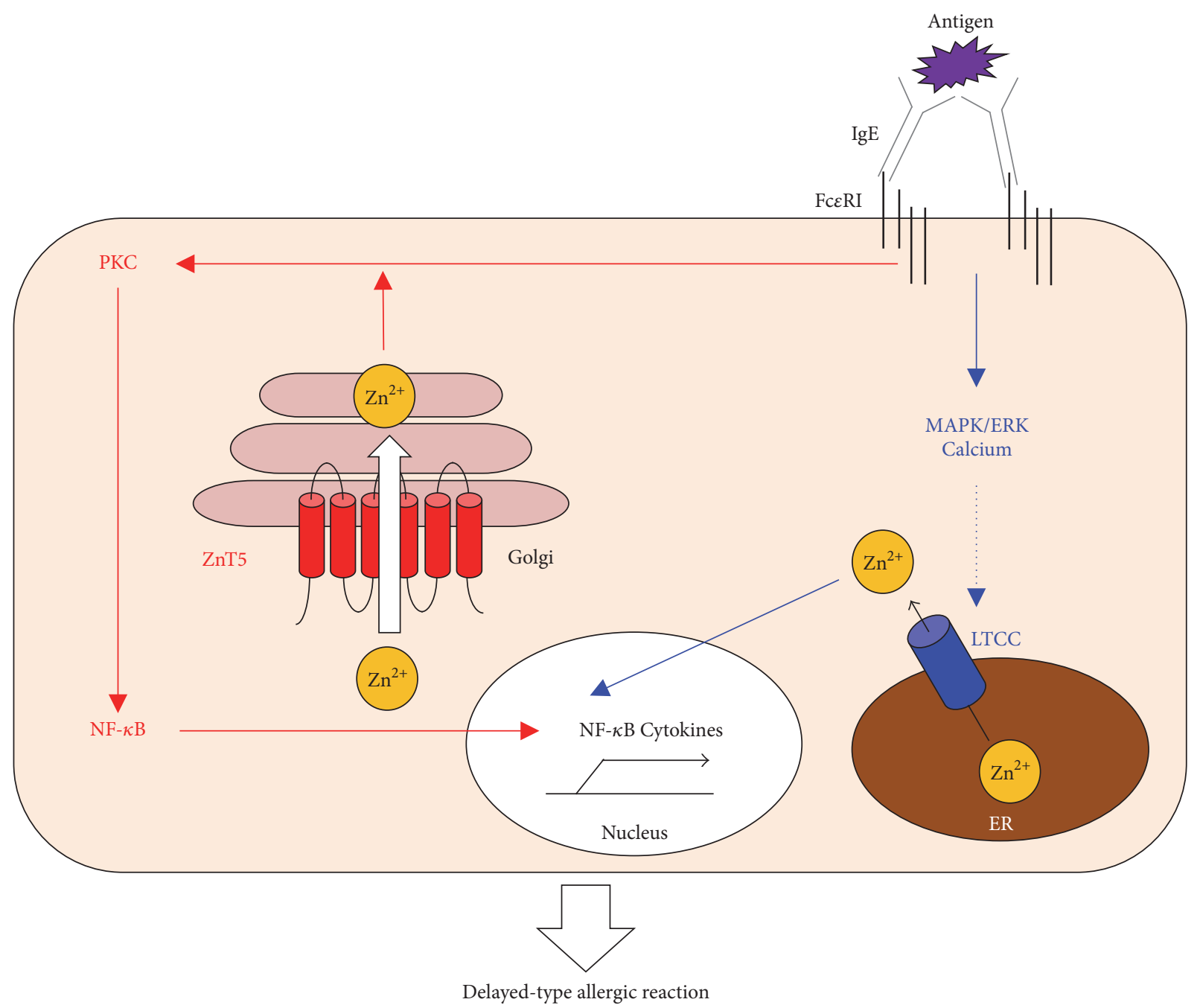

FIGURE 3: Zn uptake via LTCC and ZnT5 controls the FceRI-mediated delayed allergic response by mast cells. Zn is indispensable for FceRImediated mast-cell activation. Upon antigen sensitization, LTCC (blue) on the ER membrane acts as a Zn gatekeeper and can rapidly increase the intracellular-free $\mathrm{Zn}$ levels in the perinuclear region dependent on calcium and MAPK/ERK signaling ( $\mathrm{Zn}$ wave). The released $\mathrm{Zn}$ then regulates the DNA-binding activity of NF- $\kappa$ B followed by cytokine production. Simultaneously, ZnT5 (red) on the Golgi membrane takes up $\mathrm{Zn}$ to regulate the translocation of PKC to the plasma membrane. The resultant NF- $\kappa$ B activation induces inflammatory cytokine production. Thus, these $\mathrm{Zn}$ gatekeepers and $\mathrm{Zn}$ transporter control mast-cell-mediated, delayed-type allergic reactions.

and we here focus on the roles of $\mathrm{Zn}$ and $\mathrm{Zn}$ transporters specifically in DCs, T cells, and B cells, which are bridging populations that enable crosstalk between the innate and adaptive immune systems.

4.1. DCs. DCs are professional antigen-presenting cells that are differentiated from a hematopoietic lineage and are important in linking the innate and adaptive immune systems. They circulate as immature cells and differentiate into mature DCs when activated by exposure to pathogens. In this process, DCs take up antigens, degrade them into peptides, load the antigenic peptides onto major histocompatibility complex II (MHC-II), and finally present the peptide-MHCII complex on their cell surface to antigen-specific $\mathrm{CD} 4^{+}$ helper T (Th) cells to initiate immune responses [86].

When mouse DCs in vivo or in vitro are exposed to a ligand for toll-like receptor 4 (TLR4), lipopolysaccharide
(LPS), which is a component of bacterial cell walls, the DCs elicit cell maturation with a reduction in intracellular-free $\mathrm{Zn}$ levels and an increase in surface MHC-II and costimulatory molecules (Figure 4) [80]. During the maturation process, $\mathrm{Zn}$ transporter expression is changed: ZIP6 and ZIP10 are downregulated, while ZnT1, ZnT4, and ZnT6 are upregulated for a net decrease in cytosolic $\mathrm{Zn}$ content. Chemical $\mathrm{Zn}$ chelation by the membrane-permeable $\mathrm{Zn}$ chelator TPEN $(N, N, N, N$ tetrakis (2-pyridylmethyl) ethylenediamine) mimics this phenomenon, while the forced introduction of $\mathrm{Zn}$ or the ectopic expression of ZIP6 suppresses LPS-induced DC maturation. Consistent with these findings, DCs that overexpress ZIP6 fail to activate antigen-specific $\mathrm{CD} 4^{+} \mathrm{Th}$ cells. Microscopic analysis revealed that $\mathrm{Zn}$ facilitates the endocytosis of MHC-II but inhibits the trafficking of MHCII from the lysosome/endosome compartments to the plasma membrane. These results suggest that a reduction in cellular 


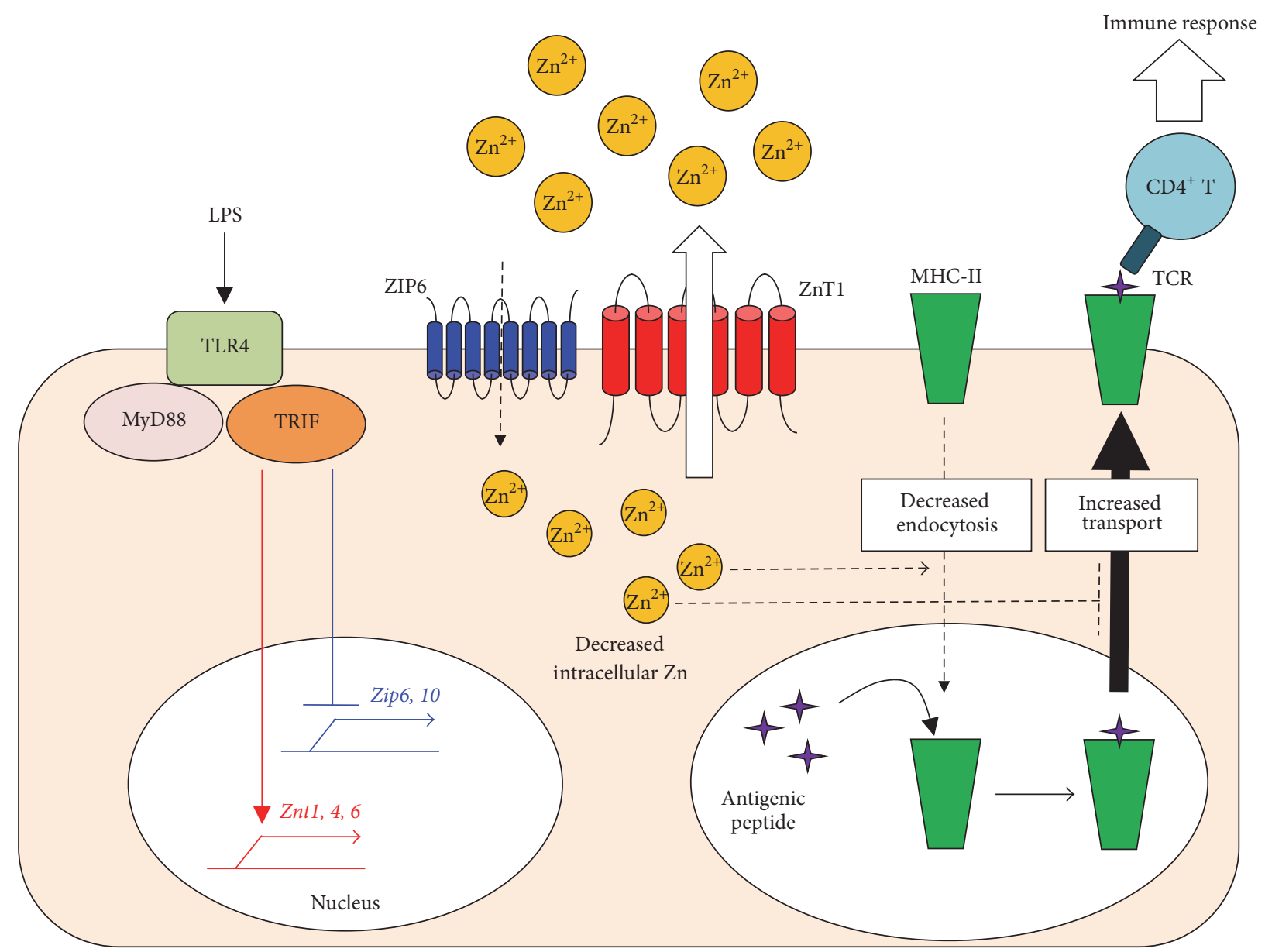

FIGURE 4: A decrease in intracellular-free $\mathrm{Zn}$ is critical for LPS-mediated CD4 ${ }^{+}$T-cell activation by DCs. LPS, a TLR4 ligand, induces DC activation, which initiates a maturation signal mediated by MyD88 and TRIF. TRIF-mediated signaling reduces the expression of ZIPs (blue) and increases that of ZnTs (red), resulting in a net decrease in the intracellular-free $\mathrm{Zn}$ level in DCs. This reduction of intracellular-free $\mathrm{Zn}$ is critical for the antigen presentation via MHC-II molecules and the subsequent activation of antigen-specific CD $4^{+} \mathrm{T}$ cells.

$\mathrm{Zn}$ is required for proper antigen presentation via $\mathrm{MHC}-\mathrm{II}$ to elicit adaptive immune responses (Figure 4) [80].

Although $\mathrm{ZnD}$ causes immunodeficiency [1], it can also induce abnormal skin inflammations accompanied by erythematous rashes, scaly plaques, and ulcers on the acral and periorificial areas [17-20]. In fact, these paradoxical symptoms are particularly obvious in patients with hereditary and acquired $\mathrm{AE}$, in which an immunostimulated skin inflammation develops in areas subject to repeated contact [19]. Interestingly, dietary $\mathrm{ZnD}$ mice with allergic contact dermatitis (ACD) induced by dinitrofluorobenzene (DNFB) show markedly reduced ear swelling, while those with irritant contact dermatitis (ICD) induced by croton oil (CrO) exhibit augmented ear swelling [60]. Histological analysis revealed that the ICD lesions in $\mathrm{ZnD}$ mice have features similar to cutaneous manifestations in human AE lesions, such as subcorneal vacuolization and epidermal pallor. In $\mathrm{ZnD}$ mice, damaged epidermal keratinocytes release adenosine $5^{\prime}$ triphosphate (ATP) that leads to ICD, which can be ameliorated by locally injecting soluble nucleoside triphosphate diphosphohydrolase. Notably, experiments in ex vivo organ culture showed that $\mathrm{Zn}$ chelation by TPEN enhances the
ATP release in response to $\mathrm{CrO}$ whereas TPEN alone does not, suggesting that a combination of $\mathrm{ZnD}$ and chemical irritants synergistically increases the release of ATP from keratinocytes [60].

These findings raise the question of why a $\mathrm{ZnD}$ environment enhances the irritant-induced ATP release from keratinocytes. Langerhans cells (LCs) are epidermis-resident DCs that act as sentinels to orchestrate immune responses against foreign antigens, including pathogens, in the skin [87]. LCs exclusively express the ecto-NTPDase CD39 [88], which protects the cells against ATP-mediated inflammatory signals by hydrolyzing the extracellular nucleotides released by keratinocytes [88]. Interestingly, the number of epidermal LCs is significantly reduced in $\mathrm{ZnD}$ mice [60]. A similar phenomenon is observed in the lesions of patients with $\mathrm{AE}$, but not those with atopic dermatitis or psoriasis vulgaris. Notably, LC recolonization of the epidermis and marked clinical improvement are observed in $\mathrm{AE}$ patients treated with oral Zn supplements. These data collectively suggest that inflammatory skin manifestations in $\mathrm{AE}$ patients may result from excessive ICD responses upon repeated exposure to various irritants in a $\mathrm{ZnD}$ environment, due to the aberrant 
ATP release from epidermal keratinocytes and the depletion of LCs [60].

\section{2. $T$ Cells. Activated $\mathrm{T}$ cells are largely divided into $\mathrm{CD} 4^{+}$} Th cells which provide vital assistance to $B$ cells to induce antibody response and $\mathrm{CD} 8^{+}$cytotoxic $\mathrm{T}$ cells (CTLs) which induce cell death by direct interactions with pathogeninfected cells or tumor cells. During an adaptive immune response, both types of cells establish an immunological memory that is poised to respond rapidly and effectively to a pathogen that has been previously encountered (recall response). Th-cell populations are involved in autoimmunity, allergic response, and tumor immunity. Upon T-cell receptor (TCR) activation in a particular cytokine milieu, naive $\mathrm{CD} 4^{+} \mathrm{T}$ cells can differentiate into several subsets, including Th1, Th2, Th17, and regulatory $\mathrm{T}$ (Treg) cells. The resultant $\mathrm{CD} 4^{+} \mathrm{T}$-cell subsets are characterized by their functions and patterns of cytokine production [89]. Th1 cells promote cellmediated immune responses against intracellular pathogens and produce the cytokines, interferon gamma (IFN- $\gamma$ ), TNF$\alpha / \beta$, and IL-2. These cytokines promote macrophage activation, nitric oxide production, and CTL proliferation, leading to the phagocytosis and destruction of microbial pathogens. The differentiation and expansion of Th1 cells are driven mainly by IL-12, which induces the signal transducers and activator of transcription (STAT) 4-dependent Th1-specific transcription factor T-bet. T-bet promotes the expression of IFN- $\gamma$ and IL-12Rb2, which, together with IL-12Rb1, form a functional IL-12 receptor complex to further stimulate IFN$\gamma$-induced Thl differentiation. Exaggerated Thl responses are associated with autoimmune diseases, including rheumatoid arthritis, multiple sclerosis, inflammatory bowel disease, and type 1 diabetes. Th2 cells, which are required for humoral immunity against extracellular pathogens, secrete IL-4, IL-5, IL-6, IL-10, and IL-13. Exposing TCR-stimulated CD4 $4^{+} \mathrm{T}$ cells to IL-4 induces the STAT6-dependent expression of the Th2 master transcriptional regulator GATA-3 and then produces IL-5 and IL-13 for cell expansion. IL-2, IL-7, or thymic stromal lymphopoietin (TSLP) is also required during Th2 differentiation to activate STAT5, which cooperates with GATA3 to promote the T-cell production of IL-4. IL-4 regulates the clonal expansion of Th2 cells and, along with IL-13, promotes the B-cell production of IgE and alternative macrophage activation. Excessive Th2-type immune responses have been implicated in the development of chronic allergic inflammation and asthma. Th17 cells are involved in immune responses mounted against specific fungi and extracellular bacteria. In mice, Th17 cells develop from naive $\mathrm{CD} 4^{+} \mathrm{T}$ cells in the presence of TGF- $\beta$ and IL- 6 , inducing the STAT3-dependent expression of IL-21, the IL-23 receptor, and the transcription factor ROR $\gamma \mathrm{t}$. IL-21 and IL-23 regulate the establishment and clonal expansion of Th17 cells, while $\mathrm{ROR} \gamma \mathrm{t}$-induced gene expression leads to the secretion of IL17A, IL-17F, and IL-22. Cytokines produced by Th17 cells stimulate resident cells to secrete chemokines to recruit neutrophils and macrophages to inflammation sites. The persistent secretion of Th17 cytokines promotes chronic inflammation and may be involved in the pathogenesis of inflammatory and autoimmune diseases such as rheumatoid arthritis, multiple sclerosis, and inflammatory bowel disorders. Tregs play an indispensable role in maintaining the immunological unresponsiveness to self-antigens and in suppressing excessive immune responses that would be deleterious to the host.

$\mathrm{T}$ cells reach maturity after passing through several stages in the thymus [90]. They begin as $\mathrm{CD}^{-} \mathrm{CD}^{-}$doublenegative (DN) thymocytes, pass through a double-positive (DP) stage ( $\mathrm{CD}^{+} \mathrm{CD}^{+}$thymocytes), become single-positive (SP) T cells ( $\mathrm{CD} 4^{+} \mathrm{CD}^{-}$or $\mathrm{CD} 8^{+} \mathrm{CD} 4^{-} \mathrm{SP}$ thymocytes), and finally leave the thymus as naive $\mathrm{T}$ cells. In humans and mammalian model animals, $\mathrm{ZnD}$ causes thymic atrophy with a substantial reduction of DP thymocytes and a subsequent decline in mature T-cell counts [91-101]. Patients with AE due to a ZIP4 mutation show symptoms of severe $\mathrm{ZnD}$ characterized by immunodeficiency with thymic atrophy and lymphopenia and by recurrent infections in $\sim 30 \%$ of patients [102]. One mechanism that contributes to this thymic atrophy is accelerated apoptosis, due in part to chronically elevated levels of glucocorticoids (corticosterone in particular) from the adrenal glands [103-108], although human thymocytes are relatively resistant to glucocorticoids [106]. In fact, adrenalectomized mice fed a $\mathrm{ZnD}$ diet show little change in thymic weight $[105,106]$, whereas, in adult mice given a corticosteroid implant, the thymus size is substantially reduced [109]. Furthermore, antiapoptotic proteins such as B-cell lymphoma- (BCL-) 2 and BCL-X are reduced in $\mathrm{ZnD}$ DP thymocytes, increasing their susceptibility to apoptosis compared to DN thymocytes, Th cells, and CTLs [110-112]. In vitro studies showed that more lymphocytes and thymocytes undergo apoptosis when cultured in a Zn-free medium [113] or with a Zn chelator [114-116] as opposed to when cultured in a normal medium.

Another potential mechanism underlying thymic atrophy in a $\mathrm{ZnD}$ environment is the impaired activity of the nonapeptide thymulin (H-Pyr-Ala-Lys-Ser-Gln-Gly-GlySer-Asn-OH) [117-119]. Thymulin, which is secreted by thymic epithelial populations, binds a specific high-affinity receptor on $\mathrm{T}$ cells to promote $\mathrm{T}$-cell maturation, cytotoxic function, and IL-2 production [117, 118, 120-122]. Serum thymulin is present but less active in $\mathrm{ZnD}$ subjects; its activity is restored by $\mathrm{Zn}$ supplementation [117], suggesting that $\mathrm{Zn}$ promotes a conformational change in thymulin to confer biological activity [119]. Thus, the $\mathrm{ZnD}$-induced thymic atrophy could result from the combination of increased glucocorticoid levels, an impairment of thymulin's activity and impaired cell-intrinsic survival function.

Which $\mathrm{Zn}$ transporter regulates early T-cell differentiation in the thymus is poorly understood. Mice with a targeted ZIP3 deletion have lower DP thymocyte counts and increased counts of $\mathrm{CD}^{+} \mathrm{SP}$ or $\mathrm{CD}^{+}$SP thymocytes under a $\mathrm{Zn}$ limiting condition [14], suggesting that ZIP3 loss accelerates T-cell maturation. However, deleting ZIP3 does not change $\mathrm{Zn}$ homeostasis in terms of the levels of essential metals or the expression of $\mathrm{Zn}$-responsive genes. These data suggest that ZIP3 plays an ancillary role in $\mathrm{Zn}$ homeostasis to generate naive T-cell populations in the thymus [14].

In contrast to the susceptibility of DP thymocytes to $\mathrm{ZnD}$, mature $\mathrm{CD}^{+}$and $\mathrm{CD}^{+} \mathrm{T}$ cells are relatively resistant 
to $\mathrm{ZnD}$ and survive well in the atrophying thymus [112]. However, in adrenalectomized mice fed a $\mathrm{ZnD}$ diet, the Th-cell helper functions that promote the differentiation of B cells into antibody-secreting plasma cells are impaired, even though there is little change in the thymic weight [105, 106], indicating that $\mathrm{Zn}$ status is important not only in the early development of $\mathrm{T}$ cells but also in their activation and function in periphery. Indeed, microarray analysis showed that even a modest $\mathrm{Zn}$ deficiency in mice changes the expression of 1,200 genes related to the proliferation, survival, and response of T cells [123]. Furthermore, IL-2 production is decreased in mice with a marginal $\mathrm{ZnD}$, even though there is no thymic shrinkage or increase in glucocorticoid concentrations $[124,125]$. Several in vitro studies demonstrated that $\mathrm{Zn}$ is important for T-cell proliferation in response to cytokines and mitogenic agents $[9,126-132] . \mathrm{Zn}$ is required during the mid to late G1 phase [10], the transition to $S$ phase [133], and the transition to the G2 and M phases [134, 135]. Phytohemagglutinin- (PHA-) stimulated lymphocytes from mildly $\mathrm{ZnD}$ patients contain a greater proportion of cells at $\mathrm{S}$ phase than those from normal human controls; this increase is reversed by $\mathrm{Zn}$ supplementation [136].

TCR signaling is indispensable for cell proliferation, differentiation, and survival and for cytokine production [137]. Upon antigen recognition, the TCR stimulates LCK to activate the PI3K-AKT pathway and phosphorylate the immunoreceptor tyrosine-based activation motifs (ITAMs) of the TCR/CD3 complex on the cytosolic side, thereby recruiting and activating ZAP70, which in turn recruits and activates downstream adaptor or scaffold proteins such as SLP-76, VAV, and ITK. ITK activates phospholipase $\mathrm{C}$, gamma 1 (PLC $\gamma 1$ ), which leads to the production of the second messengers diacylglycerol (DAG) and inositol trisphosphate (IP3). DAG further activates the protein kinase $\mathrm{C}$ theta $(\mathrm{PKC} \theta), \mathrm{NF}-\kappa \mathrm{B}$, and MAPK/ERK pathways. On the other hand, IP3 induces the ER to release calcium. Calciumbound calmodulin activates the phosphatase calcineurin (CN), which promotes IL-2 gene transcription through the nuclear translocation of transcription factor NFAT.

$\mathrm{Zn}$ is reported to affect components of the TCR signaling pathway $[138,139]$. Some reports indicate that increased intracellular $\mathrm{Zn}$ concentrations enhance the activation of LCK and PKC [140] but inhibit the activity of the phosphatase CN $[141,142]$ and other PTPases. Stimulating $T$ cells by incubation with DCs induces an influx of $\mathrm{Zn}$ across the plasma membrane via ZIP6, which rapidly increases the intracellular $\mathrm{Zn}$ concentration at spatially restricted regions; the $\mathrm{Zn}$ is concentrated near the immunological synapse between the T cell and DC [143]. This phenomenon enhances ZAP70 and inhibits the recruitment of tyrosine phosphatase SHP-1 (a negative regulator for TCR signaling) to the TCR, resulting in a prolonged calcium influx that contributes to cell proliferation and cytokine production (Figure 5). This mechanism suggests an important potential role for the $\mathrm{Zn}$ transporter-Zn signaling axis in TCR signaling.

ZIP8 is highly expressed in human T cells and is markedly upregulated by in vitro stimulation with TCR [144]. RNA interference against ZIP8 reduces the ZIP8 expression and attenuates the production of IFN- $\gamma$ and perforin in human
T cells. In contrast, overexpressing ZIP8 enhances the IFN$\gamma$ production. ZIP8 localizes to lysosomes, and labile $\mathrm{Zn}$ decreases in the lysosomes and increases in the cytoplasm during T-cell activation. Further analysis revealed that ZIP8$\mathrm{Zn}$ reduces the $\mathrm{CN}$ phosphatase activity, leading to higher IFN- $\gamma$ production following prolonged phosphorylation of the transcription factor CREB. Thus, ZIP8-Zn signaling positively controls TCR-induced cytokine production (Figure 5) [144]. In fact, several studies indicate that $\mathrm{ZnD}$ suppresses the production of cytokines such as IL-1, IL-2, IL-4, and IFN- $\gamma$ [93, 145-152]. In Th0 and Th1 cell lines cultured in low $\mathrm{Zn}$ medium, mitogenic stimulation reduces the mRNA expression of IL-2 and IFN- $\gamma$ [153]. In this context, experiments in humans revealed that $\mathrm{Zn}$ deprivation decreases the production of Thl cytokines but has less effect on the production of Th2 cytokines (IL-4, IL-6, and IL-10), so the Th1/Th2 balance is disturbed and shifted toward Th2 $[145,149]$. Consistent with this observation, cell-mediated immunity and delayed-type hypersensitivity fail in Th1 cells with a $\mathrm{ZnD}$ condition, whereas $\mathrm{Th} 2$-dependent function appears to be less affected $[94,145,149,154,155]$. In contrast, $\mathrm{Zn}$ enhances production of the Thl cytokine IFN- $\gamma$ and decreases the Th2 cytokine IL-10 in human PBMCs exposed to allergens [156]. These dysregulations associated with low $\mathrm{Zn}$ are restored by $\mathrm{Zn}$ supplementation [145, 149, 157-162], suggesting that $\mathrm{Zn}$ controls the Th1/Th2 balance.

Tregs play a special role in controlling immune homeostasis by suppressing undesirable immune responses [163]. Several reports indicate that $\mathrm{Zn}$ treatment prevents T-cellmediated immune responses in vivo and in vitro [78, 164-166] and enhances the number and activity of Tregs in some cases $[156,167,168]$. In vitro, $\mathrm{Zn}$ attenuates Th17 differentiation, which is controlled by IL-6-induced STAT3 activation during chronic inflammation by suppressing STAT3 activation [89]. Reflecting this result, in vivo studies show that moderate $\mathrm{Zn}$ treatment inhibits Th17-cell development and disease severity in mice with experimental autoimmune encephalomyelitis (EAE) and collagen-induced arthritis (CIA) [78, 167]. Moreover, at higher concentrations, $\mathrm{Zn}$ suppresses T-cell proliferation in mice [169] and cytokine production in human Jurkat [154] and $\mathrm{CD}^{+} \mathrm{T}$ cells [144]. Although the molecular mechanisms underlying these concentrationdependent effects of $\mathrm{Zn}$ is largely unknown, they may involve the overcapacity of the intracellular buffering system to absorb large amounts of $\mathrm{Zn}$ and a breakdown of the system of $\mathrm{Zn}$ transport. Thus, $\mathrm{Zn}$ immunomodulates cytokine signaling in $\mathrm{T}$ cells to control antigen-specific immune reactions.

Although many reports have revealed the importance of nutritional $\mathrm{Zn}$ in classical Th subsets, Zn's effect in vivo on follicular helper $\mathrm{T}$ (Tfh) cells, an important component in humoral immunity, has not yet been addressed. Tfh cells are a subset of specialized effector Th cells that help B cells and are essential for germinal center (GC) formation, which promotes the generation of high-affinity antibody-secreting plasma cells and memory B cells in vivo [170]. Although it is still controversial whether Tfh cells are differentiated from a lineage that is independent from those of $\mathrm{Th}$, Th2, Th17, and Treg cells, Th cells differentiate through 


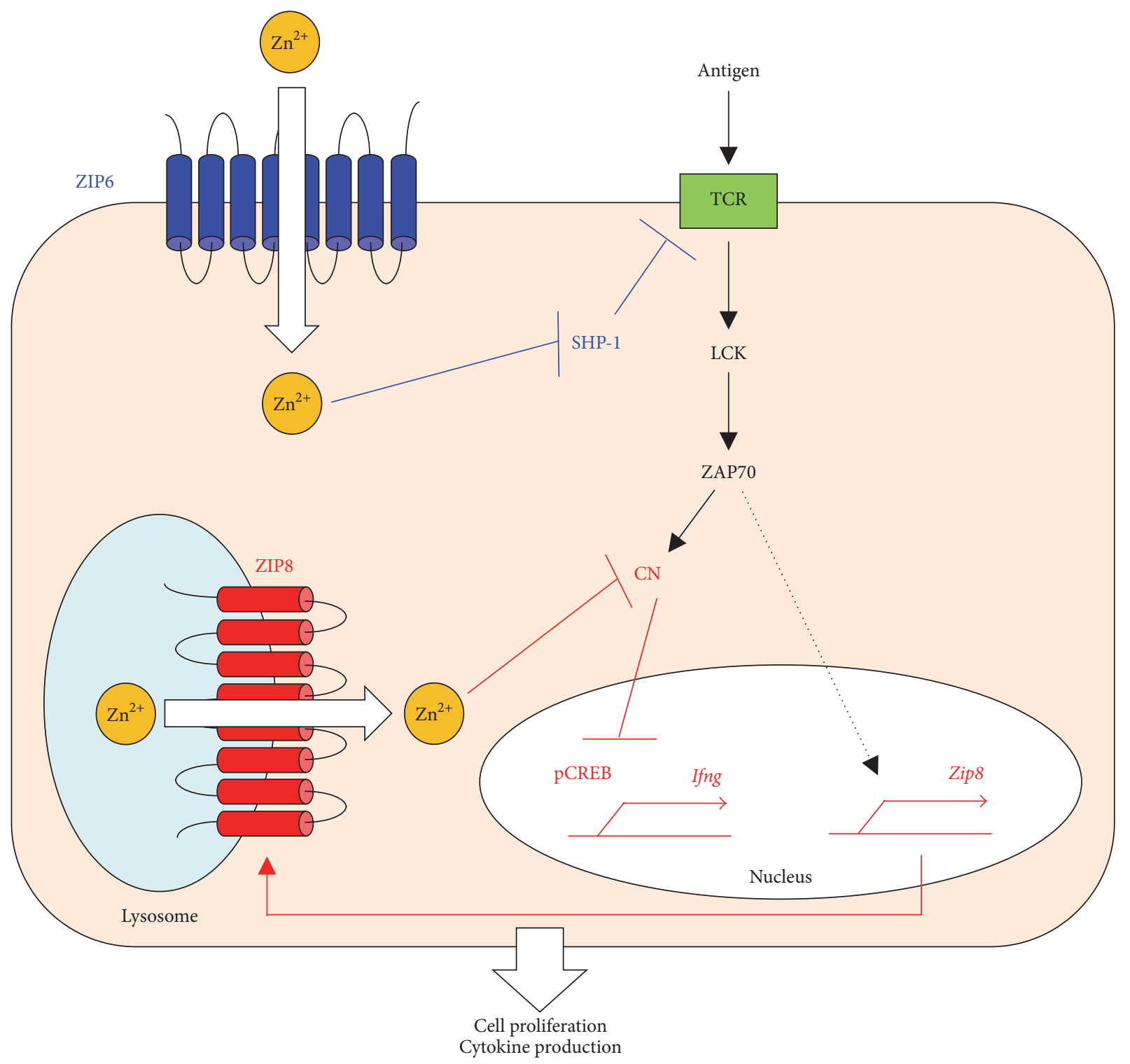

Figure 5: Zn uptake via ZIP6 and ZIP8 potentiates TCR signaling. Through the interaction of DCs and T cells, TCR activation rapidly increases cytoplasmic Zn concentrations, particularly at the subsynaptic compartment, in a manner dependent on ZIP6 (blue). The enhanced influx of $\mathrm{Zn}$ reduces SHP-1 recruitment to the TCR activation complex, thereby augmenting ZAP70 activation and leading to a sustained influx of calcium. On the other hand, TCR activation increases ZIP8 expression, which exports Zn out of the lysosome and into the cytoplasm (red). The resultant increase in cytoplasmic $\mathrm{Zn}$ inhibits $\mathrm{CN}$, leading to increased CREB activation and the subsequent expression of IFN- $\gamma$. Thus, Zn facilitates TCR's functions in proliferation and IFN- $\gamma$ production.

multistage and multifactorial processes that accommodate significant heterogeneity. Tfh-cell differentiation begins with the priming of naive $\mathrm{CD} 4^{+} \mathrm{T}$ cells by DCs. Early Tfh cells can migrate to the border between the periarterial lymphatic sheath (PALS) and B-cell follicles; this migration depends on the CXCR5 chemokine receptor. Finally, the Tfh cells mature in B-cell follicles. Tfh cells express relatively high levels of BCL6, a critical regulator of Tfh differentiation, and secrete IL-4 and IL-21, which cause B cells to induce class-switch recombination (CSR) for immunoglobulin (Ig) (e.g., IgM to IgG1 and IgE) and to elicit GC persistence, respectively [170, 171]. IL-2 antagonizes Tfh differentiation in a T-cell-intrinsic manner, and IL-2 deficiency augments the generation of Tfh cells and enhances GC formation [172]. $\mathrm{ZnD}$ impairs the T-cell-induced IL-2 production [145, 149, $154]$ but also compromises GC formation, thereby decreasing the subsequent IgG1 production [27]; thus, it is possible that $\mathrm{ZnD}$ also affects the generation of Tfh cells. This idea is supported by the fact that BCL6 bears a C-terminal $\mathrm{Zn}$ cluster, consisting of six $\mathrm{Zn}$-finger domains, that is necessary for its DNA binding to target genes [173]. Future studies should focus on clarifying Zn's role and identifying the $\mathrm{Zn}$ transporter involved in Tfh-cell generation in a variety of immunological contexts. 
4.3. B Cells. B cells play crucial roles in the humoral immune response, which is a major weapon in the adaptive immune system $[174,175]$. B cells develop initially in the bone marrow. Pro- $\mathrm{B}$ cells commit to pre-B cells followed by immature (IMM) B cells, which express BCR on their cell membrane. The IMM B cells then migrate to the spleen, where they further differentiate into transitional (TR) B cells and then into mature B-cell populations such as follicular (FO) and marginal zone (MZ) B cells.

Mature B cells, which are classified as professional antigen-presenting cells along with DCs, capture and process antigens taken up by specific BCRs, load antigenic peptide onto MHC-II, and present it to $\mathrm{CD} 4^{+}$Th cells. Among the mature B cells, FO B cells account for the majority of splenic B cells and are crucial for T-cell-dependent (TD) immune responses. During an immune response, activated FO B cells form the GC in the follicle with the help of Tfh cells, and they undergo massive expansion, with somatic hypermutation and CSR (e.g., IgM to IgG1) of the Ig genes to acquire a highaffinity Ig [176]. In contrast, MZ B cells, which are noncirculating, mediate rapid T-cell-independent (TI) immune responses against blood-borne pathogens.

Cook-Mills and Fraker indicate that $\mathrm{ZnD}$ has little effect on antibody secretion [177]. However, the plaque-forming cell (PFC) assays in this study were interpreted by evaluating the antibody-secreting ability of the surviving residual cells in $\mathrm{ZnD}$ mice on a per-cell basis not on a whole-organ scale. Other reports show that $\mathrm{ZnD}$ depresses both $\mathrm{TD}$ and TI antibody responses [96, 99, 178, 179]. In addition, $\mathrm{ZnD}$ reduces the TD antibody responses against sheep red blood cells by $90 \%$ of control $[96,125]$ and reduces the TI antibody responses against dextran by $50 \%$ of control $[124,180]$. In contrast, both the IgM and IgG PFC activities are restored when $\mathrm{ZnD}$ mice are fed a normal diet, although the recovery of IgG PFC is greatly delayed $[96,178]$. These observations strongly suggest that $\mathrm{Zn}$ controls antibody-mediated humoral immune responses.

The ZIP-family member ZIP10, which is a cell-membrane-localized transporter, is expressed in splenic B cells [27]. ZIP10 transports $\mathrm{Zn}$ from the extracellular fluid to the intracellular space $[27,28]$. The targeted disruption of ZIP10 in antigen-presenting cells, including mature B cells, diminishes antigen-specific antibody responses, in particular, the production of IgG antibodies, which is correlated with severe GC-formation impairment in a B-cell-intrinsic manner [27]. Furthermore, in immunized mice fed a $\mathrm{ZnD}$ diet, the GC B-cell population and the antigen-specific IgG1 response are significantly reduced, partly mimicking the phenotypes in ZIP10-deficient mice. Although the number of mature resting FO B cells is significantly decreased in ZIP10-deficient mice in vivo, their proliferative activity in response to BCR stimulation is also reduced in vitro. Moreover, TI responses are also impaired in ZIP10-deficient mice, which have an intact number of MZ B cells. Collectively, these results suggest that Zn not only quantitatively controls FO B-cell maintenance but also qualitatively regulates the BCR signaling pathway. Thus, the abrogated TD antibody response in ZIP10-deficient mice cannot be fully explained by the reduced FO B-cell count; impaired BCR signaling is also appreciably involved.
BCR signaling is transmitted through multiple pathways to mediate cell activation, proliferation, and death [181184]. BCR signaling is initiated by LYN, an SRC-family protein tyrosine kinase (Src-PTK). LYN activates SYK, which activates downstream kinases and transcription factors such as MAPK, PI3K, and NF- $\kappa$ B [176]. Paradoxically, the overall BCR signaling is enhanced in ZIP10-deficient B cells, with hyperactivated LYN and SYK and downstream ERK, AKT, and NF- $\kappa$ B in response to BCR stimulation [27]. This phenomenon is partly attributed to a $20 \%$ decrease in the expression and $50 \%$ decrease in the overall activity of CD45R PTPase that inhibits LYN activity (Figure 6) [185], although its precise role in regulating Src-PTKs remains controversial [186-190]. Generally, Zn has a negative impact on PTPase activity, as reported for the receptor PTPase beta [191], PTP1B [192], and SHP-1 (a negative regulator for BCR signaling) [143]. It has also been proposed that intracellular $\mathrm{Zn}$ is incorporated into the Golgi by ZnT5/6/7 and then released into the cytosol by ZIP9, which in turn inhibits PTPase activity to activate BCR signaling in DT40 cells [193]. If these situations are applicable to ZIP10-deficient B cells, there would be a loss of the suppressive effect of $\mathrm{Zn}$ normally exerted via ZIP10, resulting in reduced LYN activity due to enhanced CD45R PTPase activity. However, the opposite result is reported: downregulated CD45R PTPase activity is accompanied by enhanced LYN activation after BCR stimulation [27]. The involvement of CSK, which downregulates the LYN activity by increasing phosphorylation at its inhibitory site [194], is also unlikely, since $\mathrm{Zn}$ completely suppresses CSK's function [195]. In fact, when an active form of CD45R recombinant protein is coincubated with high concentration of $\mathrm{Zn}$ in vitro, its PTPase activity is suppressed [27]. However, the forced introduction of $\mathrm{Zn}$ into ZIP10-deficient B cells partially recovers the CD45R PTPase activity and suppresses LYN activation ex vivo in the stimulated cells [27]. Taken together, these results suggest that ZIP10-Zn signaling regulates the expression of CD45R while simultaneously (and indirectly) enhancing the CD45R PTPase activity through a Zn-dependent process rather than by a direct effect on PTPase activity (Figure 6).

Although the detail mechanism underlying how ZIP10Zn signaling controls the CD45R PTPase activity in vivo is currently unclear, one potential target of ZIP10-Zn signaling may be an oxidant (Figure 6). Zn negatively regulates oxidants [196], which can suppress PTPase activity [197]. The involvement of reactive oxygen species (ROS) in BCR signaling as a second messenger has been reported $[198,199]$. BCR engagement stimulates ROS production, which inhibits PTPase activity (e.g., SHP-1) around the BCR, thereby amplifying BCR signaling $[198,199]$. Another possibility is that $\mathrm{Zn}$ is involved in dimerizing $\mathrm{CD} 45$, thereby downregulating its function (Figure 6) [200]. These issues remain to be clarified. It would be interesting to investigate (1) how ZIP10 regulates the expression of CD45R, (2) how ZIP10 regulates CD45R activity in a steady state and the BCR signaling process (e.g., whether ZIP10 forms a complex with BCR clusters), (3) which microdomains ZIP10 is located in, and (4) whether ZIP10 can act through other factors to regulate BCR signaling. 


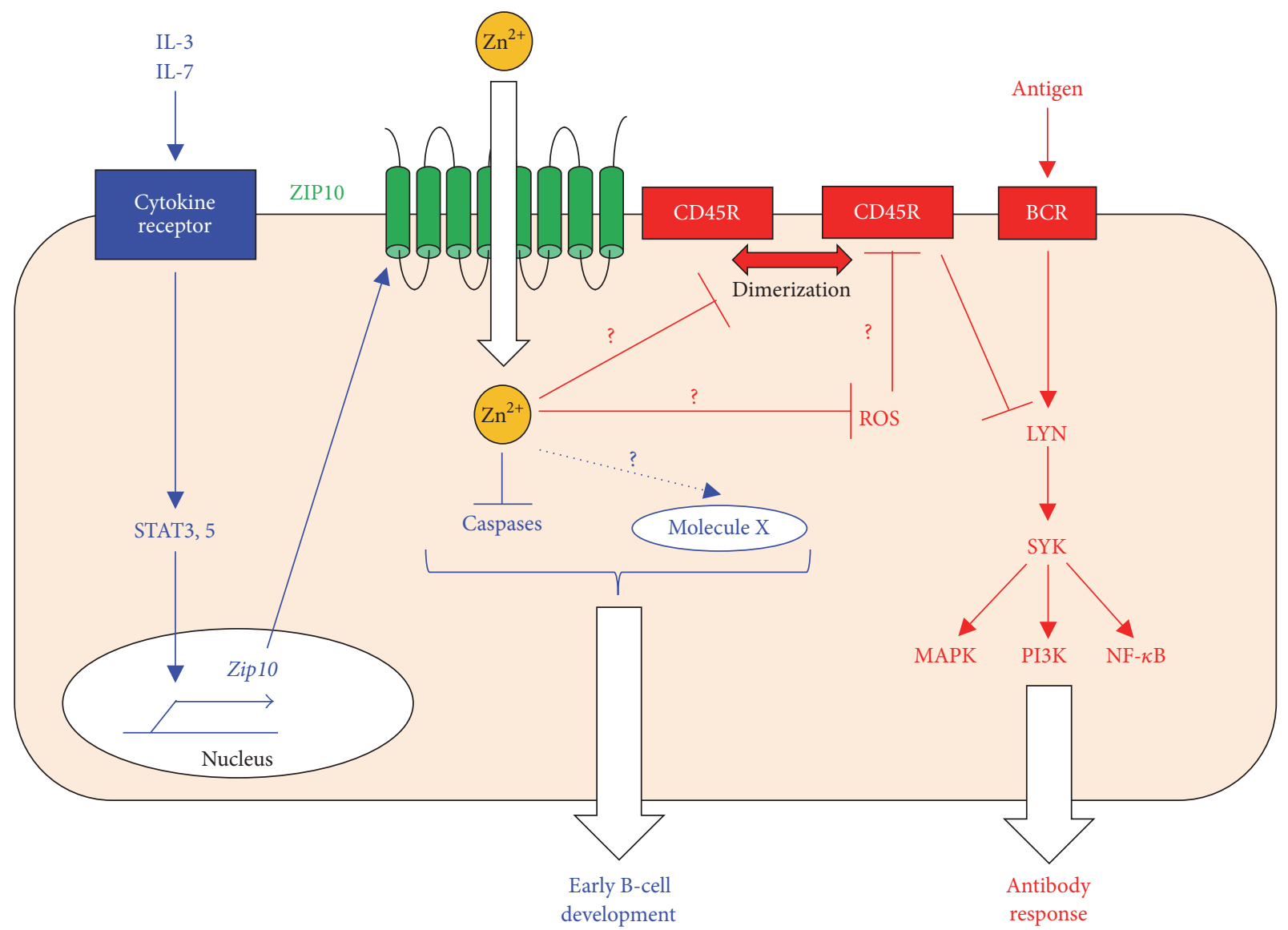

FIGURE 6: ZIP10's roles in B-cell development and function. In early B-cell development, a cytokine (1st signal) induces JAK-STAT activation (2nd signal), which is converted to an intracellular Zn signal (3rd signal) by ZIP10 upregulation. This system for converting intracellular signals promotes early B-cell survival by inhibiting caspase activation and/or by an unknown mechanism via molecule X (blue). In mature B cells, ZIP10-Zn signaling sets the threshold for the BCR signaling strength by regulating the CD45R PTPase activity (red). Thus, ZIP10 controls antibody-mediated immune responses.

Notably, ZIP10 protein levels are low in splenic B cells and even in 293T cells with ectopic ZIP10 expression [27]. There is no difference in the intracellular Zn content of ZIP10deficient and control B cells. Nevertheless, ZIP10 deficiency leads to a striking loss of mature B cells and a marked impairment of the antibody response. Given that a redundant system involving other $\mathrm{Zn}$ transporters does not appear to be active in ZIP10-deficient B cells, since there is no alteration in the expression of any other transporters, these data collectively suggest that ZIP10 is not a major contributor to the overall intracellular $\mathrm{Zn}$ homeostasis but rather set the threshold of BCR signal strength, probably by locally transporting small amounts of $\mathrm{Zn}$ from the extracellular fluid. In this regard, ZIP10 may be able to transport $\mathrm{Zn}$ more efficiently than other $\mathrm{Zn}$ transporters.

This raises the question of why, despite the augmented LYN activity, BCR-induced proliferative activity is attenuated in ZIP10-deficient B cells [27]. One possibility is that the hyperactive LYN simultaneously initiates BCR signaling and generates strong inhibitory signals mediated by FC $\gamma$ RIIbl, CD22, and PIR-B that lead to the recruitment of the SHIP1 and SHP-1 PTPases [201]. In fact, LYN ${ }^{\text {up/up }}$ mice, which express a constitutively active form of LYN, spontaneously and simultaneously activate positive (SYK) and negative (CD22, SHP-1, and SHIP-1) regulators, leading to impaired BCR-induced cell proliferation [202]. Thus, rapidly generated LYN-induced inhibitory signals may result in a signal that is insufficient for proliferation and that subsequently impairs GC formation.

It is interesting to note the similarities in immunological abnormalities in ZIP10-deficient and $\mathrm{ZnD}$ mice. $\mathrm{ZnD}$ attenuates the Thl response, which promotes Ig CSR to noncytophilic IgG2, such as IgG2a (IgG2c in C57BL/6), without affecting the Th2 response, which promotes cytophilic $\operatorname{IgG1}$ and IgE [203]. Given that ZIP10 deficiency significantly attenuates the level of IgG2c but not of IgG1 or IgE in the steady state [27], it is tempting to speculate that the loss of ZIP10 affects the signal transduction mediated by Th1 cytokines such as IFN $-\gamma$ while that mediated by Th 2 cytokines in resting $B$ cells remains intact.

Immunological memory, which involves memory B cells and long-lived plasma cells (PCs), is primarily generated through GC reactions. Hence, it is not surprising that memory-recall responses to previously encountered antigens 
are attenuated in $\mathrm{ZnD}$ animals $[74,167,168,173]$, since a $\mathrm{ZnD}$ or ZIP10-deficient environment considerably attenuates GC formation [27]. These findings suggest that the impaired signaling through $\mathrm{BCR}$ in the mature B cells from these mice may be not sufficient to support their differentiation during GC reaction. Therefore, immunological memory cannot be properly generated in these mice. Further investigation will clarify this issue.

Early B-cell development is adversely affected by $\mathrm{ZnD}$ $[109,204]$. Mice fed a diet marginally deficient in $\mathrm{Zn}$ show a $50 \%$ decline in pre-B and $25 \%$ decline in immature Bcell populations [177]. Given that steroid-implanted mice have markedly reduced numbers of pre- $B$ and immature $B$ cells in the bone marrow $[109,205]$, the effects of $\mathrm{ZnD}$ on early B-cell development might be partly explained by the effect of glucocorticoids, as is also the case with $\mathrm{T}$ cells. ZnD primarily affects B-cell precursors; resting mature $\mathrm{B}$ cells are relatively resistant to $\mathrm{ZnD}$. Indeed, a detailed study revealed that the number of FO B cells and their levels of intracellular-free $\mathrm{Zn}$ were unchanged in mice fed a $\mathrm{ZnD}$ diet for 2 weeks [27], even though these mice clearly showed growth retardation and reduced serum $\mathrm{Zn}$ $[27,60]$. Such an environment changes the expression levels of some $\mathrm{Zn}$ transporters and metallothioneins, suggesting that an unknown mechanism of resistance involving the altered expression of $\mathrm{Zn}$ mediators somehow maintains $\mathrm{Zn}$ homeostasis and avoids cell death due to insufficient $\mathrm{Zn}$. However, specifically ablating ZIP10 in antigen-presenting cells causes a significant reduction in mature FO B cells [27]. Furthermore, the forced chelation of intracellular $\mathrm{Zn}$ by TPEN induces apoptotic cell death of mature B cells. Since the loss of ZIP10 affects neither the expression of other plasma membrane-localized $\mathrm{Zn}$ transporters nor the intracellular $\mathrm{Zn}$ content under normal conditions, these data suggest that ZIP10 plays a definitive role in mature B-cell maintenance by locally targeting the responsible molecules. In light of the enhanced overall BCR signaling already discussed, it appears that the ZIP10-deficient phenotype is a partial phenocopy of the $\mathrm{LYN}^{\text {up/up }}$ phenotype, since $\mathrm{LYN}^{\text {up/up }}$ mice also have significantly fewer resting mature B cells, probably due to enhanced signaling above a certain threshold [202]. However, LYN activation does not appear to be upregulated in ZIP10-deficient B cells in the steady state, indicating that ZIP10 maintains mature B cells through a LYN-independent mechanism [27].

ZIP10 is expressed on the surface of pro-B cells at a relatively high level compared to other bone marrow-resident B-cell subsets [28]. Specifically deleting ZIP10 in pan-B cells leads to splenic atrophy with a marked reduction of peripheral B cells due to a decreased number of pro-B cells in the bone marrow [28]. ZIP10 ablation enhances the activities of the cystein-aspartic acid proteases (caspases) 3, 8, 9, and 12 in pro-B cells, resulting in increased apoptotic cell death that can be mimicked by chemically chelating intracellular $\mathrm{Zn}$ using TPEN and can be restored by $\mathrm{Zn}$ supplementation. This finding indicates that ZIP10-Zn signaling inhibits the apoptosis induced by activated caspases and promotes proB-cell survival in a cell-autonomous manner (Figure 6).
JAK-STAT signaling induced by cytokine stimulation controls pro-B-cell survival and development [206] but also has oncogenic effects [207]. IL-3 or IL-7 stimulation induces ZIP10 expression through the JAK-STAT pathway [28]. In human follicular lymphoma, ZIP10 is abundant in constitutively active STAT3- and STAT5-expressing cells. In silico findings also show that ZIP10 is strongly expressed in acute myeloid and lymphoid leukemia. Thus, cytokine stimulation (the first signal) activates the JAK-STAT pathway (the second signal), which further induces ZIP10 expression and eventually generates ZIP10-Zn signals (the third signal). In this way, ZIP10-Zn signaling may control fate decisions in lymphocyte progenitors under physiological conditions and exacerbate malignancy under pathological conditions, according to the highly regulated pattern of ZIP10 expression [28]. Given that a rigorous selection process in early B-cell development ensures functionality and avoids autoreactivity by eliminating the majority of newly formed B cells through apoptosis [208], suppressing or augmenting the ZIP10-Zn signaling axis may lead to lymphopenia on one hand or autoimmunity and malignancy on the other. The molecular mechanism by which ZIP10-Zn signaling inhibits apoptosis is currently unclear. $\mathrm{ZnD}$ influences the gene expression of the BCL/BAX family [209], which is downregulated to eliminate nonreactive or autoreactive $\mathrm{B}$ cells during the developmental process but is also overexpressed in follicular lymphoma cells [210]. Since ZIP10-deficient pro-B cells show lower intracellular Zn level [28], ZIP10 function may be coordinated with these antiapoptotic factors.

Taken together, these findings underscore the definitive role of ZIP10-Zn signaling not only in antibody responses but also in early B-cell development and the maintenance of mature B cells (Figure 6). Collectively, these studies provide deep insights into how Zn controls lymphocyte homeostasis and function.

\section{Conclusion}

The importance of nutritional $\mathrm{Zn}$ for the immune systems is evident from the immunodeficiency seen in $\mathrm{ZnD}$ mice. Although Zn's function as a key structural or catalytic component in more than 300 enzymes and transcription factors are well known, there is a growing body of evidence that supports Zn's role as a second messenger in a variety of cellular activities. The intracellular $\mathrm{Zn}$ concentration can be changed by immune-related extracellular stimulation, and the subsequent crosstalk between $\mathrm{Zn}$ and signaling components facilitates the transduction of signaling pathways for immune homeostasis and functions. However, contradictory results have been reported regarding the effects of $\mathrm{Zn}$ on the immune system. Some studies show that excessive $\mathrm{Zn}$ impairs T-cell proliferation and cytokine production. Although the molecular mechanisms underlying the concentration-dependent effects of $\mathrm{Zn}$ are poorly understood, they probably involve the capacity of the intracellular buffering system to absorb large amounts of $\mathrm{Zn}$ and a breakdown of the system of $\mathrm{Zn}$ transport. Collectively, these findings strongly suggest that cellular $\mathrm{Zn}$ levels can determine the threshold for $\mathrm{Zn}$ functions in physiology and pathophysiology. In this regard, 


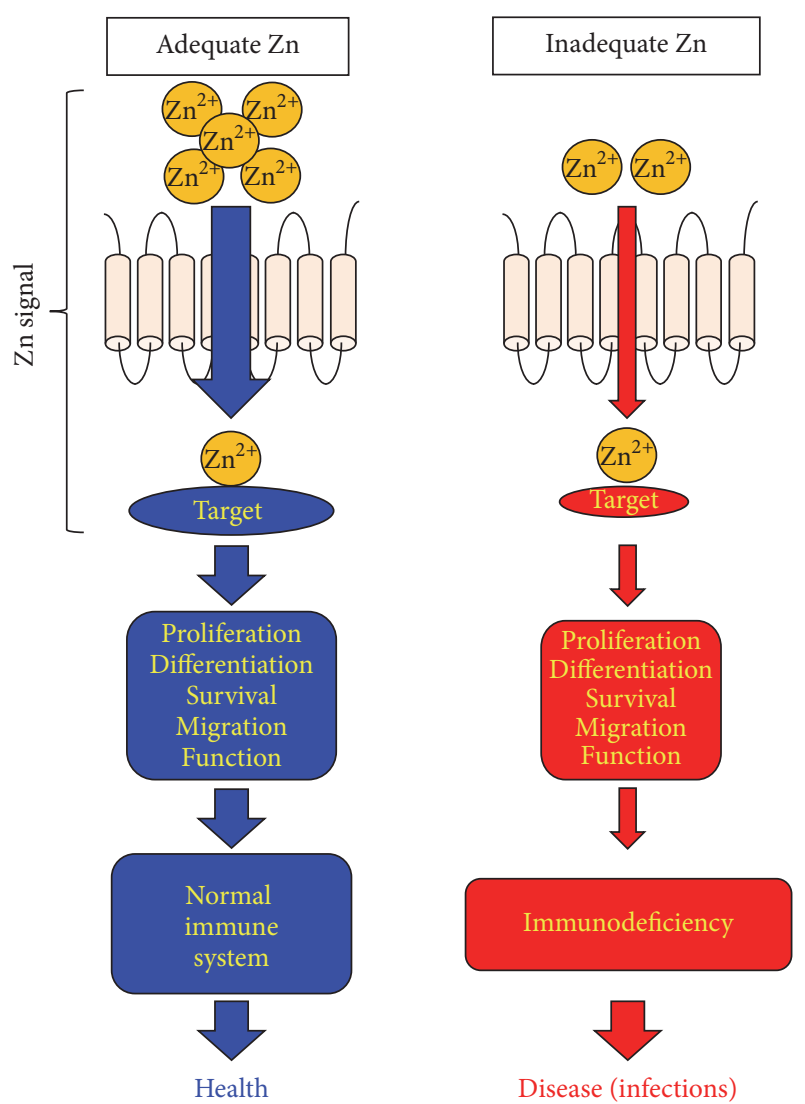

Figure 7: Zn-signal axes in immune system. Each Zn-signal axis targets a specific molecule and controls a variety of cellular activities such as proliferation, differentiation, survival, migration, and function via a distinct signaling pathway to control immune homeostasis and functions. $\mathrm{ZnD}$ (red) impairs these $\mathrm{Zn}$-signal axes and leads to disease if there is no redundant machinery.

it is reasonable that $\mathrm{Zn}$ signaling by $\mathrm{Zn}$ transporters and channels would be tightly controlled in physiology.

In this review, we focused mainly on the physiological effects of $\mathrm{Zn}$ signaling mediated by specific $\mathrm{Zn}$ transporter families in the adaptive immune system. Each Zn-signal axis targets a specific molecule, allowing $\mathrm{Zn}$ to influence a wide range of cellular activities such as proliferation, differentiation, survival, migration, and function by selectively regulating distinct signaling pathways in immune systems (Figure 7). The disruption of a $\mathrm{Zn}$-signal axis by $\mathrm{ZnD}$ can cause immunodeficiency if there is no redundant machinery. However, there are still few studies of the involvement of the individual $\mathrm{Zn}$ transporters in immune homeostasis and functions; thus, research into $\mathrm{Zn}$ signaling in humoral immunity has barely scratched the surface. Since $\mathrm{ZnD}$ depresses both primary and secondary immune responses, it will be important to use both nutritional and genetic approaches to investigate $\mathrm{Zn}$ signaling in the prominent cell types involved in each immunological process (e.g., Th cells, GC B cells, and memory $\mathrm{B}$ and memory $\mathrm{T}$ cells). These analyses may provide a deeper understanding of the relevance of $\mathrm{Zn}$ signals in adaptive immunity and lead to novel therapeutic drugs and vaccines for immune-related disorders and infections.

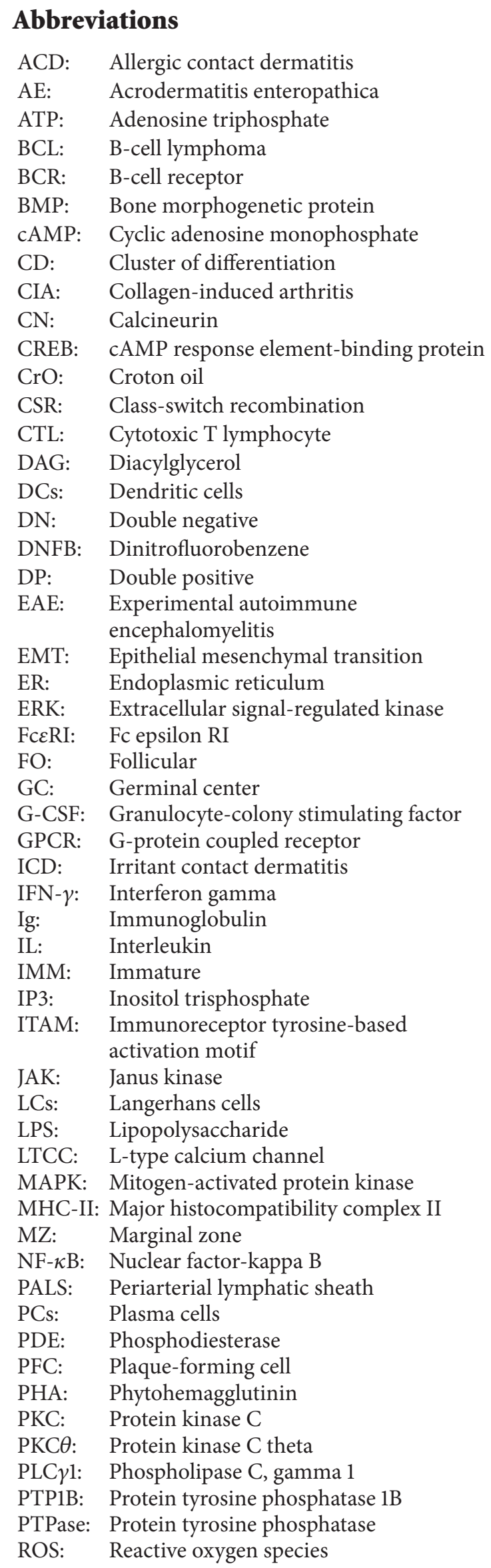


SCD-EDS: Spondylocheirodysplastic form of Ehlers-Danlos syndrome

SLC: $\quad$ Solute carrier family

SMAD: Sma- and Mad-related family

SP: $\quad$ Single positive

Src-PTKs: SRC-family protein tyrosine kinases

STAT: $\quad$ Signal transducers and activator of transcription

SYK: $\quad$ Spleen tyrosine kinase

TCR: $\quad$ T-cell receptor

TD: $\quad$ T-cell dependent

Tfh: $\quad$ Follicular helper $T$ cell

TGF- $\beta$ : Transforming growth factor beta

Th: $\quad$ Helper T cell

TI: $\quad$ T-cell independent

TLR: $\quad$ Toll-like receptor

TNF- $\alpha / \beta$ : Tumor necrosis factor alpha/beta

TPEN: $\quad N, N, N, N$ tetrakis (2-pyridylmethyl) ethylenediamine

Treg: $\quad$ Regulatory $\mathrm{T}$ cell

TSLP: Thymic stromal lymphopoietin

ZIP: $\quad$ Zrt/Irt-like protein family

$\mathrm{ZnD}: \quad$ Zinc deficiency (deficient)

ZnT: $\quad$ Zinc transporter family.

\section{Competing Interests}

The authors declare that there is no conflict of interests regarding the publication of this paper.

\section{Acknowledgments}

The authors thank Drs. Toshio Hirano, Masaru Taniguchi, and Shigeo Koyasu for their generous support. This study was supported by grants from the Japan Society for the Promotion of Science (no. 23592239 to Toshiyuki Fukada), Nestlé Nutrition Council Japan Research Grants (Toshiyuki Fukada), the NOVARTIS Foundation for the Promotion of Science (Toshiyuki Fukada), and the SENSHIN Medical Research Foundation (Toshiyuki Fukada).

\section{References}

[1] A. S. Prasad, "Discovery of human zinc deficiency: 50 years later," Journal of Trace Elements in Medicine and Biology, vol. 26, no. 2-3, pp. 66-69, 2012.

[2] C. Andreini, L. Banci, I. Bertini, and A. Rosato, "Counting the zinc-proteins encoded in the human genome," Journal of Proteome Research, vol. 5, no. 1, pp. 196-201, 2006.

[3] R. Gamsjaeger, C. K. Liew, F. E. Loughlin, M. Crossley, and J. P. Mackay, "Sticky fingers: zinc-fingers as protein-recognition motifs," Trends in Biochemical Sciences, vol. 32, no. 2, pp. 63-70, 2007.

[4] K. R. Wessells and K. H. Brown, "Estimating the global prevalence of zinc deficiency: results based on zinc availability in national food supplies and the prevalence of stunting," PLoS ONE, vol. 7, no. 11, Article ID e50568, 2012.

[5] A. H. Shankar and A. S. Prasad, "Zinc and immune function: the biological basis of altered resistance to infection," The American Journal of Clinical Nutrition, vol. 68, no. 2, pp. 447S-463S, 1998.
[6] K. Brudzynska, A. Ploszajska, R. Roszczyk, and Z. Walter, "Internation of zinc ions with DNA-dependent RNA polymerases A, B and C isolated from calf thymus," Molecular Biology Reports, vol. 8, no. 2, pp. 77-83, 1982.

[7] K. H. Falchuk, A. Krishan, and B. L. Vallee, "DNA distribution in the cell cycle of Euglena gracilis. Cytofluorometry of zinc deficient cells," Biochemistry, vol. 14, no. 15, pp. 3439-3444, 1975.

[8] R. A. Good, A. West, N. K. Day, Z. W. Dong, and G. Fernandes, "Effects of undernutrition of host cell and organ function," Cancer Research, vol. 42, pp. 737s-746s, 1982.

[9] F. Grummt, C. Weinmann-Dorsch, J. Schneider-Schaulies, and A. Lux, "Zinc as a second messenger of mitogenic induction. Effects on diadenosine tetraphosphate (Ap4A) and DNA synthesis," Experimental Cell Research, vol. 163, no. 1, pp. 191-200, 1986.

[10] A. S. Prasad, F. W. J. Beck, L. Endre, W. Handschu, M. Kukuruga, and G. Kumar, "Zinc deficiency affects cell cycle and deoxythymidine kinase gene expression in HUT-78 cells," Journal of Laboratory and Clinical Medicine, vol. 128, no. 1, pp. 51-60, 1996.

[11] J. P. Slater, A. S. Mildvan, and L. A. Loeb, "ZINC in DNA polymerases," Biochemical and Biophysical Research Communications, vol. 44, no. 1, pp. 37-43, 1971.

[12] T. Fukada, S. Hojyo, and B. H. Bin, Zinc Signal in Growth Control and Bone Diseases, Springer Japan, 2014.

[13] T. Fukada and T. Kambe, "Molecular and genetic features of zinc transporters in physiology and pathogenesis," Metallomics, vol. 3, no. 7, pp. 662-674, 2011.

[14] J. Dufner-Beattie, Z. L. Huang, J. Geiser, W. Xu, and G. K. Andrews, "Generation and characterization of mice lacking the zinc uptake transporter ZIP3," Molecular and Cellular Biology, vol. 25, no. 13, pp. 5607-5615, 2005.

[15] J. Dufner-Beattie, Z. L. Huang, J. Geiser, W. Xu, and G. K. Andrews, "Mouse ZIP1 and ZIP3 genes together are essential for adaptation to dietary zinc deficiency during pregnancy," Genesis, vol. 44, no. 5, pp. 239-251, 2006.

[16] J. L. Peters, J. Dufner-Beattie, W. Xu et al., "Targeting of the mouse Slc39a2 (Zip2) gene reveals highly cell-specific patterns of expression, and unique functions in zinc, iron, and calcium homeostasis," Genesis, vol. 45, no. 6, pp. 339-352, 2007.

[17] G. K. Andrews, "Regulation and function of Zip4, the acrodermatitis enteropathica gene," Biochemical Society Transactions, vol. 36, no. 6, pp. 1242-1246, 2008.

[18] S. Küry, B. Dréno, S. Bézieau et al., "Identification of SLC39A4, a gene involved in acrodermatitis enteropathica," Nature Genetics, vol. 31, no. 3, pp. 239-240, 2002.

[19] E. Maverakis, M. A. Fung, P. J. Lynch et al., "Acrodermatitis enteropathica and an overview of zinc metabolism," Journal of the American Academy of Dermatology, vol. 56, no. 1, pp. 116124, 2007.

[20] K. Wang, B. Zhou, Y.-M. Kuo, J. Zemansky, and J. Gitschier, "A novel member of a zinc transporter family is defective in acrodermatitis enteropathica," The American Journal of Human Genetics, vol. 71, no. 1, pp. 66-73, 2002.

[21] J. Dufner-Beattie, B. P. Weaver, J. Geiser et al., "The mouse acrodermatitis enteropathica gene Slc39a4 (Zip4) is essential for early development and heterozygosity causes hypersensitivity to zinc deficiency," Human Molecular Genetics, vol. 16, no. 12, pp. 1391-1399, 2007.

[22] J. Geiser, K. J. T. Venken, R. C. de Lisle, and G. K. Andrews, "A mouse model of acrodermatitis enteropathica: loss of intestine zinc transporter ZIP4 (Slc39a4) disrupts the stem cell niche and intestine integrity," PLoS Genetics, vol. 8, no. 6, Article ID e1002766, 2012. 
[23] H. Guo, X. Jin, T. Zhu et al., "SLC39A5 mutations interfering with the BMP/TGF- $\beta$ pathway in non-syndromic high myopia," Journal of Medical Genetics, vol. 51, no. 8, pp. 518-525, 2014.

[24] M. Gálvez-Peralta, L. He, L. F. Jorge-Nebert et al., "ZIP8 zinc transporter: indispensable role for both multiple-organ organogenesis and hematopoiesis in utero," PLOS ONE, vol. 7, no. 5, Article ID e36055, 2012.

[25] J.-H. Kim, J. Jeon, M. Shin et al., "Regulation of the catabolic cascade in osteoarthritis by the zinc-ZIP8-MTF1 axis," Cell, vol. 156, no. 4, pp. 730-743, 2014.

[26] J. K. Pickrell, T. Berisa, J. Z. Liu, L. Ségurel, J. Y. Tung, and D. A. Hinds, "Detection and interpretation of shared genetic influences on 42 human traits," Nature Genetics, vol. 48, no. 7, pp. 709-717, 2016.

[27] S. Hojyo, T. Miyai, H. Fujishiro et al., "Zinc transporter SLC39A10/ZIP10 controls humoral immunity by modulating B-cell receptor signal strength," Proceedings of the National Academy of Sciences of the United States of America, vol. 111, no. 32, pp. 11786-11791, 2014.

[28] T. Miyai, S. Hojyo, T. Ikawa et al., "Zinc transporter SLC39A10/ ZIP10 facilitates antiapoptotic signaling during early B-cell development," Proceedings of the National Academy of Sciences of the United States of America, vol. 111, no. 32, pp. 11780-11785, 2014.

[29] L. Zhao, E. Oliver, K. Maratou et al., "The zinc transporter ZIP12 regulates the pulmonary vascular response to chronic hypoxia," Nature, vol. 524, no. 7565, pp. 356-360, 2015.

[30] B.-H. Bin, T. Fukada, T. Hosaka et al., "Biochemical characterization of human ZIP13 protein: a homo-dimerized zinc transporter involved in the Spondylocheiro dysplastic EhlersDanlos syndrome," The Journal of Biological Chemistry, vol. 286, no. 46, pp. 40255-40265, 2011.

[31] B.-H. Bin, S. Hojyo, T. Hosaka et al., "Molecular pathogenesis of spondylocheirodysplastic ehlers-danlos syndrome caused by mutant ZIP13 proteins," EMBO Molecular Medicine, vol. 6, no. 8, pp. 1028-1042, 2014.

[32] B. H. Bin, S. Hojyo, T. R. Lee, and T. Fukada, "Spondylocheirodysplastic Ehlers-Danlos syndrome (SCD-EDS) and the mutant zinc transporter ZIP13," Rare Diseases, vol. 2, no. 1, Article ID e974982, 2014.

[33] T. Fukada, Y. Asada, K. Mishima, S. Shimoda, and I. Saito, "Slc39a13/Zip13: a crucial zinc transporter involved in tooth development and inherited disorders," Journal of Oral Biosciences, vol. 53, no. 1, pp. 1-12, 2011.

[34] T. Fukada, N. Civic, T. Furuichi et al., "The zinc transporter SLC39A13/ZIP13 is required for connective tissue development; its involvement in BMP/TGF- $\beta$ signaling pathways," PLoS ONE, vol. 3, no. 11, Article ID e3642, 2008.

[35] S. Hojyo, T. Fukada, S. Shimoda et al., "The zinc transporter SLC39A14/ZIP14 controls G-protein coupled receptormediated signaling required for systemic growth," PLoS ONE, vol. 6, no. 3, Article ID e18059, 2011.

[36] T. B. Aydemir, H. S. Sitren, and R. J. Cousins, “The zinc transporter Zip14 influences c-Met phosphorylation and hepatocyte proliferation during liver regeneration in mice," Gastroenterology, vol. 142, no. 7, pp. 1536.e5-1546.e5, 2012.

[37] C. Troche, T. Beker Aydemir, and R. J. Cousins, "Zinc transporter Slc39a14 regulates inflammatory signaling associated with hypertrophic adiposity," American Journal of PhysiologyEndocrinology and Metabolism, vol. 310, no. 4, pp. E258-E268, 2016.
[38] K. Tuschl, E. Meyer, L. E. Valdivia et al., "Mutations in SLC39A14 disrupt manganese homeostasis and cause childhood-onset parkinsonism-dystonia," Nature Communications, vol. 7, Article ID 11601, 2016.

[39] G. K. Andrews, H. Wang, S. K. Dey, and R. D. Palmiter, "Mouse zinc transporter 1 gene provides an essential function during early embryonic development," Genesis, vol. 40, no. 2, pp. 7481, 2004.

[40] W. Chowanadisai, B. Lönnerdal, and S. L. Kelleher, "Identification of a mutation in SLC30A2 (ZnT-2) in women with low milk zinc concentration that results in transient neonatal zinc deficiency," The Journal of Biological Chemistry, vol. 281, no. 51, pp. 39699-39707, 2006.

[41] N. Itsumura, Y. Inamo, F. Okazaki et al., "Compound heterozygous mutations in SLC30A2/ZnT2 results in low milk zinc concentrations: a novel mechanism for zinc deficiency in a breast-fed infant," PLoS ONE, vol. 8, no. 5, Article ID e64045, 2013.

[42] N. Itsumura, Y. Kibihara, K. Fukue et al., "Novel mutations in SLC30A2 involved in the pathogenesis of transient neonatal zinc deficiency," Pediatric Research, vol. 80, no. 4, pp. 586-594, 2016.

[43] S. Lee, S. R. Hennigar, S. Alam, K. Nishida, and S. L. Kelleher, "Essential role for zinc transporter 2 (ZnT2)-mediated zinc transport in mammary gland development and function during lactation," The Journal of Biological Chemistry, vol. 290, no. 21, pp. 13064-13078, 2015.

[44] C. Sindreu, R. D. Palmiter, and D. R. Storm, "Zinc transporter ZnT-3 regulates presynaptic Erk1/2 signaling and hippocampusdependent memory," Proceedings of the National Academy of Sciences of the United States of America, vol. 108, no. 8, pp. 33663370, 2011.

[45] P. A. Adlard, J. M. Parncutt, D. I. Finkelstein, and A. I. Bush, "Cognitive loss in zinc transporter-3 knock-out mice: a phenocopy for the synaptic and memory deficits of Alzheimer's disease?" The Journal of Neuroscience, vol. 30, no. 5, pp. 1631$1636,2010$.

[46] L. Huang and J. Gitschier, "A novel gene involved in zinc transport is deficient in the lethal milk mouse," Nature Genetics, vol. 17, no. 3, pp. 292-297, 1997.

[47] K. Inoue, K. Matsuda, M. Itoh et al., "Osteopenia and malespecific sudden cardiac death in mice lacking a zinc transporter gene, Znt5," Human Molecular Genetics, vol. 11, no. 15, pp. 1775$1784,2002$.

[48] K. Nishida, A. Hasegawa, S. Nakae et al., "Zinc transporter $\mathrm{Znt5/Slc30a5}$ is required for the mast cell-mediated delayedtype allergic reaction but not the immediate-type reaction," Journal of Experimental Medicine, vol. 206, no. 6, pp. 1351-1364, 2009.

[49] L. Huang, Y. Y. Yu, C. P. Kirschke, E. R. Gertz, and K. K. C. Lloyd, "Znt7 (Slc30a7)-deficient mice display reduced body zinc status and body fat accumulation," The Journal of Biological Chemistry, vol. 282, no. 51, pp. 37053-37063, 2007.

[50] L. Huang, C. P. Kirschke, Y.-A. E. Lay, L. B. Levy, D. E. Lamirande, and P. H. Zhang, "Znt7-null mice are more susceptible to diet-induced glucose intolerance and insulin resistance," The Journal of Biological Chemistry, vol. 287, no. 40, pp. 3388333896, 2012.

[51] J. M. Wenzlau, K. Juhl, L. Yu et al., "The cation efflux transporter ZnT8 (Slc30A8) is a major autoantigen in human type 1 diabetes," Proceedings of the National Academy of Sciences of the United States of America, vol. 104, no. 43, pp. 17040-17045, 2007. 
[52] R. Sladek, G. Rocheleau, J. Rung et al., "A genome-wide association study identifies novel risk loci for type 2 diabetes," Nature, vol. 445, no. 7130, pp. 881-885, 2007.

[53] K. Lemaire, M. A. Ravier, A. Schraenen et al., "Insulin crystallization depends on zinc transporter ZnT8 expression, but is not required for normal glucose homeostasis in mice," Proceedings of the National Academy of Sciences of the United States of America, vol. 106, no. 35, pp. 14872-14877, 2009.

[54] T. J. Nicolson, E. A. Bellomo, N. Wijesekara et al., "Insulin storage and glucose homeostasis in mice null for the granule zinc transporter ZnT8 and studies of the type 2 diabetesassociated variants," Diabetes, vol. 58, no. 9, pp. 2070-2083, 2009.

[55] N. Wijesekara, F. F. Dai, A. B. Hardy et al., "Beta cell-specific Znt8 deletion in mice causes marked defects in insulin processing, crystallisation and secretion," Diabetologia, vol. 53, no. 8 , pp. 1656-1668, 2010.

[56] M. Tamaki, Y. Fujitani, A. Hara et al., "The diabetes-susceptible gene SLC30A8/ZnT8 regulates hepatic insulin clearance," The Journal of Clinical Investigation, vol. 123, no. 10, pp. 4513-4524, 2013.

[57] M. Quadri, A. Federico, T. Zhao et al., "Mutations in SLC30A10 cause parkinsonism and dystonia with hypermanganesemia, polycythemia, and chronic liver disease," American Journal of Human Genetics, vol. 90, no. 3, pp. 467-477, 2012.

[58] M. Stamelou, K. Tuschl, W. K. Chong et al., "Dystonia with brain manganese accumulation resulting from SLC30A10 mutations: a new treatable disorder," Movement Disorders, vol. 27, no. 10, pp. 1317-1322, 2012.

[59] K. Tuschl, P. T. Clayton, S. M. Gospe Jr. et al., "Syndrome of hepatic cirrhosis, dystonia, polycythemia, and hypermanganesemia caused by mutations in SLC30A10, a manganese transporter in man," American Journal of Human Genetics, vol. 90, no. 3, pp. 457-466, 2012.

[60] T. Kawamura, Y. Ogawa, Y. Nakamura et al., "Severe dermatitis with loss of epidermal Langerhans cells in human and mouse zinc deficiency," The Journal of Clinical Investigation, vol. 122, no. 2, pp. 722-732, 2012.

[61] M.-J. Liu, S. Bao, M. Gálvez-Peralta et al., "ZIP8 regulates host defense through zinc-mediated inhibition of NF- $\kappa \mathrm{B}$," Cell Reports, vol. 3, no. 2, pp. 386-400, 2013.

[62] C. Giunta, N. H. Elçioglu, B. Albrecht et al., "Spondylocheiro dysplastic form of the ehlers-danlos syndrome-an autosomalrecessive entity caused by mutations in the zinc transporter gene SLC39A13," American Journal of Human Genetics, vol. 82, no. 6, pp. 1290-1305, 2008.

[63] J. J. Bruinsma, T. Jirakulaporn, A. J. Muslin, and K. Kornfeld, "Zinc ions and cation diffusion facilitator proteins regulate Rasmediated signaling," Developmental Cell, vol. 2, no. 5, pp. 567$578,2002$.

[64] T. B. Cole, H. J. Wenzel, K. E. Kafer, P. A. Schwartzkroin, and R. D. Palmiter, "Elimination of zinc from synaptic vesicles in the intact mouse brain by disruption of the ZnT3 gene," Proceedings of the National Academy of Sciences of the United States of America, vol. 96, no. 4, pp. 1716-1721, 1999.

[65] M. Hershfinkel, A. Moran, N. Grossman, and I. Sekler, "A zincsensing receptor triggers the release of intracellular $\mathrm{Ca}^{2+}$ and regulates ion transport," Proceedings of the National Academy of Sciences of the United States of America, vol. 98, no. 20, pp. 11749-11754, 2001.

[66] Y. Li, C. J. Hough, S. W. Suh, J. M. Sarvey, and C. J. Frederickson, "Rapid translocation of $\mathrm{Zn}^{2+}$ from presynaptic terminals into postsynaptic hippocampal neurons after physiological stimulation," Journal of Neurophysiology, vol. 86, no. 5, pp. 2597-2604, 2001.

[67] G. Wei, C. J. Hough, Y. Li, and J. M. Sarvey, "Characterization of extracellular accumulation of $\mathrm{Zn}^{2+}$ during ischemia and reperfusion of hippocampus slices in rat," Neuroscience, vol. 125, no. 4, pp. 867-877, 2004.

[68] X. Xie and T. G. Smart, "Modulation of long-term potentiation in rat hippocampal pyramidal neurons by zinc," Pflügers Archiv, vol. 427, no. 5-6, pp. 481-486, 1994.

[69] R. A. Colvin, C. P. Fontaine, M. Laskowski, and D. Thomas, " $\mathrm{Zn}^{2+}$ transporters and $\mathrm{Zn}^{2+}$ homeostasis in neurons," European Journal of Pharmacology, vol. 479, no. 1-3, pp. 171-185, 2003.

[70] C. Frederickson, "Imaging zinc: old and new tools," Science's STKE, vol. 2003, no. 182, article pe18, 2003.

[71] S. Ueno, M. Tsukamoto, T. Hirano et al., "Mossy fiber $\mathrm{Zn}^{2+}$ spillover modulates heterosynaptic N-methyl-D-aspartate receptor activity in hippocampal CA3 circuits," Journal of Cell Biology, vol. 158, no. 2, pp. 215-220, 2002.

[72] D. Beyersmann and H. Haase, "Functions of zinc in signaling, proliferation and differentiation of mammalian cells," Biometals, vol. 14, no. 3-4, pp. 331-341, 2001.

[73] R. Radhakrishnan, L. J. Walter, A. Hruza et al., "Zinc mediated dimer of human interferon- $\alpha_{2 \mathrm{~b}}$ revealed by X-ray crystallography," Structure, vol. 4, no. 12, pp. 1453-1463, 1996.

[74] G. D. Smith, D. C. Swenson, E. J. Dodson, G. G. Dodson, and C. D. Reynolds, "Structural stability in the 4-zinc human insulin hexamer," Proceedings of the National Academy of Sciences of the United States of America, vol. 81, no. 22, pp. 7093-7097, 1984.

[75] T. Hirano, M. Murakami, T. Fukada, K. Nishida, S. Yamasaki, and T. Suzuki, "Roles of zinc and zinc signaling in immunity: zinc as an intracellular signaling molecule," Advances in Immunology, vol. 97, pp. 149-176, 2008.

[76] W. Maret, "Metals on the move: zinc ions in cellular regulation and in the coordination dynamics of zinc proteins," BioMetals, vol. 24, no. 3, pp. 411-418, 2011.

[77] H. Haase and W. Maret, "Intracellular zinc fluctuations modulate protein tyrosine phosphatase activity in insulin/insulin-like growth factor-1 signaling," Experimental Cell Research, vol. 291, no. 2, pp. 289-298, 2003.

[78] C. Kitabayashi, T. Fukada, M. Kanamoto et al., "Zinc suppresses Th17 development via inhibition of STAT3 activation," International Immunology, vol. 22, no. 5, pp. 375-386, 2010.

[79] S. Yamashita, C. Miyagi, T. Fukada, H. Kagara, Y.-S. Che, and T. Hirano, "Zinc transporter LIVI controls epithelialmesenchymal transition in zebrafish gastrula organizer," Nature, vol. 429, no. 6989, pp. 298-302, 2004.

[80] H. Kitamura, H. Morikawa, H. Kamon et al., "Toll-like receptormediated regulation of zinc homeostasis influences dendritic cell function," Nature Immunology, vol. 7, no. 9, pp. 971-977, 2006.

[81] S. Yamasaki, K. Sakata-Sogawa, A. Hasegawa et al., "Zinc is a novel intracellular second messenger," Journal of Cell Biology, vol. 177, no. 4, pp. 637-645, 2007.

[82] S. Yamasaki, A. Hasegawa, S. Hojyo et al., "A novel role of the L-type calcium channel alpha(1D) subunit as a gatekeeper for intracellular zinc signaling: zinc wave," PLoS ONE, vol. 7, Article ID e39654, 2012.

[83] K. M. Taylor, I. A. Muraina, D. Brethour et al., "Zinc transporter ZIP10 forms a heteromer with ZIP6 which regulates embryonic development and cell migration," Biochemical Journal, vol. 473, no. 16, pp. 2531-2544, 2016. 
[84] H. Haase and L. Rink, "Functional significance of zinc-related signaling pathways in immune cells," Annual Review of Nutrition, vol. 29, pp. 133-152, 2009.

[85] M. Maares and H. Haase, "Zinc and immunity: an essential interrelation," Archives of Biochemistry and Biophysics, 2016.

[86] I. Mellman and R. M. Steinman, "Dendritic cells: specialized and regulated antigen processing machines," Cell, vol. 106, no. 3, pp. 255-258, 2001.

[87] M. Merad, F. Ginhoux, and M. Collin, "Origin, homeostasis and function of Langerhans cells and other langerin-expressing dendritic cells," Nature Reviews Immunology, vol. 8, no. 12, pp. 935-947, 2008.

[88] N. Mizumoto, T. Kumamoto, S. C. Robson et al., "CD39 is the dominant Langerhans cell-associated ecto-NTPDase: modulatory roles in inflammation and immune responsiveness," Nature Medicine, vol. 8, no. 4, pp. 358-365, 2002.

[89] J. Zhu, H. Yamane, and W. E. Paul, "Differentiation of effector CD4 T cell populations," Annual Review of Immunology, vol. 28, pp. 445-489, 2010.

[90] R. N. Germain, "T-cell development and the CD4-CD8 lineage decision," Nature Reviews Immunology, vol. 2, no. 5, pp. 309$322,2002$.

[91] E. Brummerstedt, A. Basse, T. Flagstad, and E. Andresen, "Animal model of human disease. Acrodermatitis enteropathica, zinc malabsorption," American Journal of Pathology, vol. 87, no. 3, pp. 725-728, 1977.

[92] E. Brummerstedt, T. Flagstad, A. Basse, and E. Andresen, “The effect of zinc on calves with hereditary thymus hypoplasia (lethal trait A 46)," Acta Pathologica et Microbiologica Scandinavica, Section A: Pathology, vol. 79, no. 6, pp. 686-687, 1971.

[93] P. S. Dowd, J. Kelleher, and P. J. Guillou, "T-lymphocyte subsets and interleukin-2 production in zinc-deficient rats," British Journal of Nutrition, vol. 55, no. 1, pp. 59-69, 1986.

[94] G. Fernandes, M. Nair, K. Onoe, T. Tanaka, R. Floyd, and R. A. Good, "Impairment of cell-mediated immunity functions by dietary zinc deficiency in mice," Proceedings of the National Academy of Sciences of the United States of America, vol. 76, no. 1, pp. 457-461, 1979.

[95] P. J. Fraker, "Roles for cell death in zinc deficiency," Journal of Nutrition, vol. 135, no. 3, pp. 359-362, 2005.

[96] P. J. Fraker, P. DePasquale-Jardieu, C. M. Zwickl, and R. W. Luecke, "Regeneration of T-cell helper function in zincdeficient adult mice," Proceedings of the National Academy of Sciences of the United States of America, vol. 75, no. 11, pp. 56605664, 1978.

[97] M. H. Golden, A. A. Jackson, and B. E. Golden, "Effect of zinc on thymus of recently malnourished children," The Lancet, vol. 310, no. 8047, pp. 1057-1059, 1977.

[98] L. E. King, J. W. Frentzel, J. J. Mann, and P. J. Fraker, "Chronic zinc deficiency in mice disrupted $\mathrm{T}$ cell lymphopoiesis and erythropoiesis while B cell lymphopoiesis and myelopoiesis were maintained," Journal of the American College of Nutrition, vol. 24, no. 6, pp. 494-502, 2005.

[99] R. W. Luecke, C. E. Simonel, and P. J. Fraker, “The effect of restricted dietary intake on the antibody mediated response of the zinc deficient A/J mouse," Journal of Nutrition, vol. 108, no. 5, pp. 881-887, 1978.

[100] E. R. Miller, R. W. Luecke, D. E. Ullrey, B. V. Baltzer, B. L. Bradley, and J. A. Hoefer, "Biochemical, skeletal and allometric changes due to zinc deficiency in the baby pig," Journal of Nutrition, vol. 95, no. 2, pp. 278-286, 1968.
[101] J. M. Oleske, M. L. Westphal, S. Shore, D. Gorden, J. D. Bogden, and A. Nahmias, "Zinc therapy of depressed cellular immunity in acrodermatitis enteropathica," American Journal of Diseases of Children, vol. 133, no. 9, pp. 915-918, 1979.

[102] P. J. Fraker and L. E. King, "Reprogramming of the immune system during zinc deficiency," Annual Review of Nutrition, vol. 24, pp. 277-298, 2004.

[103] M. M. Compton and J. A. Cidlowski, "Thymocyte apoptosis a model of programmed cell death," Trends in Endocrinology \& Metabolism, vol. 3, no. 1, pp. 17-23, 1992.

[104] J. P. Concordet and A. Ferry, "Physiological programmed cell death in thymocytes is induced by physical stress (exercise)," The American Journal of Physiology, vol. 265, no. 3, pp. C626C629, 1993.

[105] P. DePasquale-Jardieu and P. J. Fraker, "The role of corticosterone in the loss in immune function in the zinc-deficient $\mathrm{A} / \mathrm{J}$ mouse," Journal of Nutrition, vol. 109, no. 11, pp. 1847-1855, 1979.

[106] P. DePasquale-Jardieu and P. J. Fraker, "Further characterization of the role of corticosterone in the loss of humoral immunity in zinc-deficient $\mathrm{A} / \mathrm{J}$ mice as determined by adrenalectomy," The Journal of Immunology, vol. 124, no. 6, pp. 2650-2655, 1980.

[107] J. Quarterman and W. R. Humpries, "Effect of zinc deficiency and zinc supplementation on adrenals, plasma steroids and thymus in rats," Life Sciences, vol. 24, no. 2, pp. 177-183, 1979.

[108] Y.-H. Zhang, K. Takahashi, G.-Z. Jiang, M. Kawai, M. Fukada, and T. Yokochi, "In vivo induction of apoptosis (programmed cell death) in mouse thymus by administration of lipopolysaccharide," Infection and Immunity, vol. 61, no. 12, pp. 5044-5048, 1993.

[109] P. J. Fraker, F. Osati-Ashtiani, M. A. Wagner, and L. E. King, "Possible roles for glucocorticoids and apoptosis in the suppression of lymphopoiesis during zinc deficiency: a review," Journal of the American College of Nutrition, vol. 14, no. 1, pp. 11-17, 1995.

[110] J. Gratiot-Deans, L. Ding, L. A. Turka, and G. Nuñez, "bcl-2 Proto-oncogene expression during human T cell development. Evidence for biphasic regulation," The Journal of Immunology, vol. 151, no. 1, pp. 83-91, 1993.

[111] J. Gratiot-Deans, R. Merino, G. Nuñez, and L. A. Turka, “Bcl-2 expression during T-cell development: early loss and late return occur at specific stages of commitment to differentiation and survival," Proceedings of the National Academy of Sciences of the United States of America, vol. 91, no. 22, pp. 10685-10689, 1994.

[112] L. E. King, F. Osati-Ashtiani, and P. J. Fraker, "Apoptosis plays a distinct role in the loss of precursor lymphocytes during zinc deficiency in mice," Journal of Nutrition, vol. 132, no. 5, pp. 974979, 2002.

[113] S. J. Martin, G. Mazdai, J. J. Strain, T. G. Cotter, and B. M. Hannigan, "Programmed cell death (apoptosis) in lymphoid and myeloid cell lines during zinc deficiency," Clinical and Experimental Immunology, vol. 83, no. 2, pp. 338-343, 1991.

[114] M. J. McCabe Jr., Shun Ai Jiang, and S. Orrenius, "Chelation of intracellular zinc triggers apoptosis in mature thymocytes," Laboratory Investigation, vol. 69, no. 1, pp. 101-110, 1993.

[115] S. Treves, P. L. Trentini, M. Ascanelli, G. Bucci, and F. Di Virgilio, "Apoptosis is dependent on intracellular zinc and independent of intracellular calcium in lymphocytes," Experimental Cell Research, vol. 211, no. 2, pp. 339-343, 1994.

[116] P. D. Zalewski, I. J. Forbes, and C. Giannakis, "Physiological role for zinc in prevention of apoptosis (gene-directed death)," Biochemistry International, vol. 24, no. 6, pp. 1093-1101, 1991.

[117] M. Dardenne, W. Savino, S. Wade, D. Kaiserlian, D. Lemonnier, and J. F. Bach, "In vivo and in vitro studies of thymulin in 
marginally zinc-deficient mice," European Journal of Immunology, vol. 14, no. 5, pp. 454-458, 1984.

[118] J. M. Pleau, V. Fuentes, J. L. Morgat, and J. F. Bach, "Specific receptors for the serum thymic factor (FTS) in lymphoblastoid cultured cell lines," Proceedings of the National Academy of Sciences of the United States of America, vol. 77, no. 5, pp. 28612865, 1980.

[119] A. S. Prasad, S. Meftah, J. Abdallah et al., "Serum thymulin in human zinc deficiency," The Journal of Clinical Investigation, vol. 82, no. 4, pp. 1202-1210, 1988.

[120] M. Dardenne, "Zinc and immune function," European Journal of Clinical Nutrition, vol. 56, supplement 3, pp. S20-S23, 2002.

[121] J. J. Haddad, "Thymulin and zinc $\left(\mathrm{Zn}^{2+}\right)$-mediated inhibition of endotoxin-induced production of proinflammatory cytokines and NF- $\kappa \mathrm{B}$ nuclear translocation and activation in the alveolar epithelium: unraveling the molecular immunomodulatory, anti-inflammatory effect of thymulin/ $\mathrm{Zn}^{2+}$ in vitro," Molecular Immunology, vol. 47, no. 2-3, pp. 205-214, 2009.

[122] B. Safieh-Garabedian, K. Ahmed, M. A. Khamashta, N. A. Taub, and G. R. V. Hughes, "Thymulin modulates cytokine release by peripheral blood mononuclear cells: a comparison between healthy volunteers and patients with systemic lupus erythematosus," International Archives of Allergy and Immunology, vol. 101, no. 2, pp. 126-131, 1993.

[123] J. B. Moore, R. K. Blanchard, W. T. McCormack, and R. J. Cousins, "cDNA array analysis identifies thymic LCK as upregulated in moderate murine zinc deficiency before $\mathrm{T}$ lymphocyte population changes," Journal of Nutrition, vol. 131, no. 12, pp. 3189-3196, 2001.

[124] P. J. Fraker, M. E. Gershwin, R. A. Good, and A. Prasad, "Interrelationships between zinc and immune function," Federation Proceedings, vol. 45, no. 5, pp. 1474-1479, 1986.

[125] P. J. Fraker, S. M. Haas, and R. W. Luecke, "Effect of zinc deficiency on the immune response of the young adult A/J mouse," Journal of Nutrition, vol. 107, no. 10, pp. 1889-1895, 1977.

[126] A. B. Chausmer, A. L. Chausmer, and N. Dajani, "Effect of mitogenic and hormonal stimulation on zinc transport in mixed lymphocyte cultures," Journal of the American College of Nutrition, vol. 10, no. 3, pp. 205-208, 1991.

[127] M. Chvapil, "Effect of zinc on cells and biomembranes," Medical Clinics of North America, vol. 60, no. 4, pp. 799-812, 1976.

[128] P. J. Fraker, P. Jardieu, and J. Cook, "Zinc deficiency and immune function," Archives of Dermatology, vol. 123, no. 12, pp. 16991701, 1987.

[129] I. Malavé, J. Rodriguez, Z. Araujo, and I. Rojas, "Effect of zinc on the proliferation response of human lymphocytes: mechanism of its mitogenic action," Immunopharmacology, vol. 20, no. 1, pp. $1-10,1990$.

[130] O. Takafumi, S. Kazue, and O. Motoyasu, "Suppression of the proliferative response of human lymphocytes to cultured allogeneic HeLa cells by zinc," Toxicology Letters, vol. 15, no. 2-3, pp. 225-230, 1983.

[131] J. L. Phillips and P. Azari, "Zinc transferrin. Enhancement of nucleic acid synthesis in phytohemagglutinin-stimulated human lymphocytes," Cellular Immunology, vol. 10, no. 1, pp. 3137, 1974

[132] Y. Tanaka, S. Shiozawa, I. Morimoto, and T. Fujita, "Role of zinc in interleukin 2 (IL-2)-mediated T-cell activation," Scandinavian Journal of Immunology, vol. 31, no. 5, pp. 547-552, 1990.

[133] K. H. Falchuk and A. Krishan, "1,10 Phenanthroline inhibition of lymphoblast cell cycle," Cancer Research, vol. 37, no. 7, pp. 2050-2056, 1977.
[134] J. E. Hesketh, "Impaired microtubule assembly in brain from zinc-deficient pigs and rats," International Journal of Biochemistry, vol. 13, no. 8, pp. 921-926, 1981.

[135] L. Serrano, J. E. Dominguez, and J. Avila, "Identification of zinc-binding sites of proteins: zinc binds to the amino-terminal region of tubulin," Analytical Biochemistry, vol. 172, no. 1, pp. 210-218, 1988.

[136] J. M. Abdallah, M. Kukuruga, A. Nakeff, and A. S. Prasad, "Cell cycle distribution defect in PHA-stimulated T lymphocytes of sickle cell disease patients," American Journal of Hematology, vol. 28, no. 4, pp. 279-281, 1988.

[137] J. E. Smith-Garvin, G. A. Koretzky, and M. S. Jordan, “T cell activation," Annual Review of Immunology, vol. 27, pp. 591-619, 2009.

[138] B. Bao, A. Prasad, F. W. J. Beck, A. Suneja, and F. Sarkar, “Toxic effect of zinc on NF- $\kappa$ B, IL-2, IL-2 receptor $\alpha$, and TNF- $\alpha$ in HUT-78 $\left(\mathrm{Th}_{0}\right)$ cells," Toxicology Letters, vol. 166, no. 3, pp. 222228, 2006.

[139] A. Hönscheid, L. Rink, and H. Haase, "T-lymphocytes: a target for stimulatory and inhibitory effects of zinc ions," Endocrine, Metabolic \& Immune Disorders_Drug Targets, vol. 9, no. 2, pp. 132-144, 2009.

[140] P. W. Kim, Z.-Y. J. Sun, S. C. Blacklow, G. Wagner, and M. J. Eck, "A zinc clasp structure tethers Lck to T cell coreceptors CD4 and CD8," Science, vol. 301, no. 5640, pp. 1725-1728, 2003.

[141] J. Huang, D. Zhang, W. Xing et al., "An approach to assay calcineurin activity and the inhibitory effect of zinc ion," Analytical Biochemistry, vol. 375, no. 2, pp. 385-387, 2008.

[142] K. Takahashi, E. Akaishi, Y. Abe et al., "Zinc inhibits calcineurin activity in vitro by competing with nickel," Biochemical and Biophysical Research Communications, vol. 307, no. 1, pp. 64-68, 2003.

[143] M. Yu, W.-W. Lee, D. Tomar et al., "Regulation of T cell receptor signaling by activation-induced zinc influx," Journal of Experimental Medicine, vol. 208, no. 4, pp. 775-785, 2011.

[144] T. B. Aydemir, J. P. Liuzzi, S. McClellan, and R. J. Cousins, "Zinc transporter ZIP8 (SLC39A8) and zinc influence IFN- $\gamma$ expression in activated human T cells," Journal of Leukocyte Biology, vol. 86, no. 2, pp. 337-348, 2009.

[145] F. W. J. Beck, A. S. Prasad, J. Kaplan, J. T. Fitzgerald, and G. J. Brewer, "Changes in cytokine production and T cell subpopulations in experimentally induced zinc-deficient humans," American Journal of Physiology - Endocrinology and Metabolism, vol. 272, no. 6, pp. E1002-E1007, 1997.

[146] A. Flynn, "Control of in vitro lymphocyte proliferation by copper, magnesium and zinc deficiency," Journal of Nutrition, vol. 114, no. 11, pp. 2034-2042, 1984.

[147] K. Gruber, M. Maywald, E. Rosenkranz, H. Haase, B. Plümäkers, and L. Rink, "Zinc deficiency adversely influences interleukin-4 and interleukin-6 signaling," Journal of Biological Regulators and Homeostatic Agents, vol. 27, no. 3, pp. 661-671, 2013.

[148] K. Moulder and M. W. Steward, "Experimental zinc deficiency: effects on cellular responses and the affinity of humoral antibody," Clinical and Experimental Immunology, vol. 77, no. 2, pp. 269-274, 1989.

[149] A. S. Prasad, "Effects of zinc deficiency on Th1 and Th2 cytokine shifts," The Journal of Infectious Diseases, vol. 182, supplement 1 , pp. S62-S68, 2000.

[150] A. S. Prasad, B. Bao, F. W. J. Beck, and F. H. Sarkar, "Zinc activates NF- $\kappa$ B in HUT-78 cells," Journal of Laboratory and Clinical Medicine, vol. 138, no. 4, pp. 250-256, 2001. 
[151] H. N. Shi, M. E. Scott, M. M. Stevenson, and K. G. Koski, "Zinc deficiency impairs $\mathrm{T}$ cell function in mice with primary infection of Heligmosomoides polygyrus (nematoda)," Parasite Immunology, vol. 16, no. 7, pp. 339-350, 1994.

[152] R. A. Winchurch, J. Togo, and W. H. Adler, "Supplemental zinc $\left(\mathrm{Zn}^{2+}\right)$ restores antibody formation in cultures of aged spleen cells II. Effects on mediator production," European Journal of Immunology, vol. 17, no. 1, pp. 127-132, 1987.

[153] B. Bao, A. S. Prasad, F. W. J. Beck, and M. Godmere, "Zinc modulates mRNA levels of cytokines," American Journal of Physiology-Endocrinology and Metabolism, vol. 285, no. 5, pp. E1095-E1102, 2003.

[154] I. Cakman, J. Rohwer, R.-M. Schütz, H. Kirchner, and L. Rink, "Dysregulation between $\mathrm{TH}_{1}$ and $\mathrm{TH}_{2} \mathrm{~T}$ cell subpopulations in the elderly," Mechanisms of Ageing and Development, vol. 87, no. 3, pp. 197-209, 1996.

[155] P. J. Fraker, C. M. Zwickl, and R. W. Luecke, "Delayed type hypersensitivity in zinc deficient adult mice: impairment and restoration of responsivity to dinitrofluorobenzene," Journal of Nutrition, vol. 112, no. 2, pp. 309-313, 1982.

[156] E. Rosenkranz, R.-D. Hilgers, P. Uciechowski, A. Petersen, B. Plümäkers, and L. Rink, "Zinc enhances the number of regulatory $\mathrm{T}$ cells in allergen-stimulated cells from atopic subjects," European Journal of Nutrition, 2015.

[157] Z. T. Cossack, "T-lymphocyte dysfunction in the elderly associated with zinc deficiency and subnormal nucleoside phosphorylase activity: effect of zinc supplementation," European Journal of Cancer and Clinical Oncology, vol. 25, no. 6, pp. 973-976, 1989.

[158] J. Duchateau, G. Delespesse, and P. Vereecke, "Influence of oral zinc supplementation on the lymphocyte response to mitogens of normal subjects," The American Journal of Clinical Nutrition, vol. 34, no. 1, pp. 88-93, 1981.

[159] L. Kahmann, P. Uciechowski, S. Warmuth et al., "Zinc supplementation in the elderly reduces spontaneous inflammatory cytokine release and restores $\mathrm{T}$ cell functions," Rejuvenation Research, vol. 11, no. 1, pp. 227-237, 2008.

[160] E. Mocchegiani, L. Santarelli, M. Muzzioli, and N. Fabris, "Reversibility of the thymic involution and of age-related peripheral immune dysfunctions by zinc supplementation in old mice," International Journal of Immunopharmacology, vol. 17, no. 9, pp. 703-718, 1995.

[161] R. S. Pekarek, H. H. Sandstead, R. A. Jacob, and D. F. Barcome, "Abnormal cellular immune responses during acquired zinc deficiency," The American Journal of Clinical Nutrition, vol. 32, no. 7, pp. 1466-1471, 1979.

[162] A. S. Prasad, J. T. Fitzgerald, J. W. Hess, J. Kaplan, F. Pelen, and M. Dardenne, "Zinc deficiency in elderly patients," Nutrition, vol. 9, no. 3, pp. 218-224, 1993.

[163] N. Ohkura, Y. Kitagawa, and S. Sakaguchi, "Development and maintenance of regulatory T cells," Immunity, vol. 38, no. 3, pp. 414-423, 2013.

[164] C. A. Campo, N. Wellinghausen, C. Faber, A. Fischer, and L. Rink, "Zinc inhibits the mixed lymphocyte culture," Biological Trace Element Research, vol. 79, no. 1, pp. 15-22, 2001.

[165] C. Faber, P. Gabriel, K.-H. Ibs, and L. Rink, "Zinc in pharmacological doses suppresses allogeneic reaction without affecting the antigenic response," Bone Marrow Transplantation, vol. 33, no. 12, pp. 1241-1246, 2004.

[166] A. Varin, A. Larbi, G. V. Dedoussis et al., "In vitro and in vivo effects of zinc on cytokine signalling in human T cells," Experimental Gerontology, vol. 43, no. 5, pp. 472-482, 2008.
[167] E. Rosenkranz, M. Maywald, R.-D. Hilgers et al., "Induction of regulatory T cells in Th1-/Th17-driven experimental autoimmune encephalomyelitis by zinc administration," Journal of Nutritional Biochemistry, vol. 29, pp. 116-123, 2016.

[168] E. Rosenkranz, C. H. Metz, M. Maywald et al., "Zinc supplementation induces regulatory $\mathrm{T}$ cells by inhibition of Sirt-1 deacetylase in mixed lymphocyte cultures," Molecular Nutrition \& Food Research, vol. 60, no. 3, pp. 661-671, 2016.

[169] N. Wellinghausen, M. Martin, and L. Rink, "Zinc inhibits interleukin-1-dependent T cell stimulation," European Journal of Immunology, vol. 27, no. 10, pp. 2529-2535, 1997.

[170] S. Crotty, "T follicular helper cell differentiation, function, and roles in disease," Immunity, vol. 41, no. 4, pp. 529-542, 2014.

[171] D. Zotos and D. M. Tarlinton, "Determining germinal centre B cell fate," Trends in Immunology, vol. 33, no. 6, pp. 281-288, 2012.

[172] A. Ballesteros-Tato, B. León, B. A. Graf et al., "Interleukin-2 inhibits germinal center formation by limiting $\mathrm{t}$ follicular helper cell differentiation," Immunity, vol. 36, no. 5, pp. 847-856, 2012.

[173] X. Mascle, O. Albagli, and C. Lemercier, "Point mutations in BCL6 DNA-binding domain reveal distinct roles for the six zinc fingers," Biochemical and Biophysical Research Communications, vol. 300, no. 2, pp. 391-396, 2003.

[174] D. Allman and S. Pillai, "Peripheral B cell subsets," Current Opinion in Immunology, vol. 20, no. 2, pp. 149-157, 2008.

[175] R. R. Hardy, P. W. Kincade, and K. Dorshkind, “The protean nature of cells in the B lymphocyte lineage," Immunity, vol. 26, no. 6, pp. 703-714, 2007.

[176] T. Kurosaki, H. Shinohara, and Y. Baba, "B cell signaling and fate decision," Annual Review of Immunology, vol. 28, pp. 21-55, 2010.

[177] J. M. Cook-Mills and P. J. Fraker, "Functional capacity of the residual lymphocytes from zinc-deficient adult mice," British Journal of Nutrition, vol. 69, no. 3, pp. 835-848, 1993.

[178] P. DePasquale-Jardieu and P. J. Fraker, "Interference in the development of a secondary immune response in mice by zinc deprivation: persistence of effects," Journal of Nutrition, vol. 114, no. 10, pp. 1762-1769, 1984.

[179] P. Zanzonico, G. Fernandes, and R. A. Good, "The differential sensitivity of T-Cell and B-Cell mitogenesis to in vitro zinc deficiency," Cellular Immunology, vol. 60, no. 1, pp. 203-211, 1981.

[180] P. J. Fraker, K. Hildebrandt, and R. W. Luecke, "Alteration of antibody-mediated responses of suckling mice to T-celldependent and independent antigens by maternal marginal zinc deficiency: restoration of responsivity by nutritional repletion," Journal of Nutrition, vol. 114, no. 1, pp. 170-179, 1984.

[181] J. C. Cambier, C. M. Pleiman, and M. R. Clark, "Signal transduction by the B cell antigen receptor and its coreceptors," Annual Review of Immunology, vol. 12, pp. 457-486, 1994.

[182] A. L. DeFranco, "The complexity of signaling pathways activated by the BCR," Current Opinion in Immunology, vol. 9, no. 3, pp. 296-308, 1997.

[183] T. Kurosaki, "Genetic analysis of B cell antigen receptor signaling," Annual Review of Immunology, vol. 17, pp. 555-592, 1999.

[184] M. Reth and J. Wienands, "Initiation and processing of signals from the B cell antigen receptor," Annual Review of Immunology, vol. 15, pp. 453-479, 1997.

[185] P. Shrivastava, T. Katagiri, M. Ogimoto, K. Mizuno, and H. Yakura, "Dynamic regulation of Src-family kinases by CD45 in B cells," Blood, vol. 103, no. 4, pp. 1425-1432, 2004.

[186] D. R. Alexander, "The CD45 tyrosine phosphatase: a positive and negative regulator of immune cell function," Seminars in Immunology, vol. 12, no. 4, pp. 349-359, 2000. 
[187] J. D. Ashwell and U. D’Oro, "CD45 and Src-family kinases: and now for something completely different," Immunology Today, vol. 20, no. 9, pp. 412-416, 1999.

[188] J. M. Penninger, J. Irie-Sasaki, T. Sasaki, and A. J. Oliveirados-Santos, "CD45: new jobs for an old acquaintance," Nature Immunology, vol. 2, no. 5, pp. 389-396, 2001.

[189] M. L. Thomas and E. J. Brown, "Positive and negative regulation of Src-family membrane kinases by CD45," Immunology Today, vol. 20, no. 9, pp. 406-411, 1999.

[190] H. Yakura, "Phosphatases and kinases in lymphocyte signaling," Immunology Today, vol. 19, no. 5, pp. 198-201, 1998.

[191] M. Wilson, C. Hogstrand, and W. Maret, "Picomolar concentrations of free zinc(II) ions regulate receptor protein-tyrosine phosphatase $\beta$ activity," The Journal of Biological Chemistry, vol. 287, no. 12, pp. 9322-9326, 2012.

[192] E. Bellomo, A. Massarotti, C. Hogstrand, and W. Maret, "Zinc ions modulate protein tyrosine phosphatase 1B activity," Metallomics, vol. 6, no. 7, pp. 1229-1239, 2014.

[193] M. Taniguchi, A. Fukunaka, M. Hagihara et al., "Essential role of the zinc transporter ZIP9/SLC39A9 in regulating the activations of Akt and Erk in B-Cell receptor signaling pathway in DT40 cells," PLoS ONE, vol. 8, no. 3, Article ID e58022, 2013.

[194] J. A. Cooper and B. Howell, "The when and how of Src regulation," Cell, vol. 73, no. 6, pp. 1051-1054, 1993.

[195] G. Sun and R. J. A. Budde, "Substitution studies of the second divalent metal cation requirement of protein tyrosine kinase CSK," Biochemistry, vol. 38, no. 17, pp. 5659-5665, 1999.

[196] S. R. Powell, "The antioxidant properties of zinc," Journal of Nutrition, vol. 130, pp. 1447S-1454S, 2000.

[197] T.-C. Meng, T. Fukada, and N. K. Tonks, "Reversible oxidation and inactivation of protein tyrosine phosphatases in vivo," Molecular Cell, vol. 9, no. 2, pp. 387-399, 2002.

[198] M. Capasso, M. K. Bhamrah, T. Henley et al., "HVCN1 modulates BCR signal strength via regulation of BCR-dependent generation of reactive oxygen species," Nature Immunology, vol. 11, no. 3, pp. 265-272, 2010.

[199] M. Reth and T. P. Dick, "Voltage control for B cell activation," Nature Immunology, vol. 11, no. 3, pp. 191-192, 2010.

[200] A. Takeda, A. Matsuda, R. M. J. Paul, and N. R. Yaseen, "CD45associated protein inhibits CD45 dimerization and up-regulates its protein tyrosine phosphatase activity," Blood, vol. 103, no. 9, pp. 3440-3447, 2004.

[201] H. Nishizumi, K. Horikawa, I. Mlinaric-Rascan, and T. Yamamoto, "A double-edged kinase lyn: a positive and negative regulator for antigen receptor-mediated signals," The Journal of Experimental Medicine, vol. 187, no. 8, pp. 1343-1348, 1998.

[202] M. L. Hibbs, K. W. Harder, J. Armes et al., "Sustained activation of Lyn tyrosine kinase in vivo leads to autoimmunity," Journal of Experimental Medicine, vol. 196, no. 12, pp. 1593-1604, 2002.

[203] S. Romagnani, “The Th1/Th2 paradigm," Immunology Today, vol. 18, no. 6, pp. 263-266, 1997.

[204] P. J. Fraker and W. G. Telford, "A reappraisal of the role of zinc in life and death decisions of cells," Proceedings of the Society for Experimental Biology and Medicine, vol. 215, no. 3, pp. 229-236, 1997.

[205] B. A. Garvy, L. E. King, W. G. Telford, L. A. Morford, and P. J. Fraker, "Chronic elevation of plasma corticosterone causes reductions in the number of cycling cells of the B lineage in murine bone marrow and induces apoptosis," Immunology, vol. 80, no. 4, pp. 587-592, 1993.

[206] L. M. Heltemes-Harris and M. A. Farrar, "The role of STAT5 in lymphocyte development and transformation," Current Opinion in Immunology, vol. 24, no. 2, pp. 146-152, 2012.
[207] J. Bromberg and J. E. Darnell Jr., "The role of STATs in transcriptional control and their impact on cellular function," Oncogene, vol. 19, no. 21, pp. 2468-2473, 2000.

[208] D. Nemazee, "Receptor editing in lymphocyte development and central tolerance," Nature Reviews Immunology, vol. 6, no. 10, pp. 728-740, 2006.

[209] A. Q. Truong-Tran, J. Carter, R. E. Ruffin, and P. D. Zalewski, "The role of zinc in caspase activation and apoptotic cell death," BioMetals, vol. 14, no. 3-4, pp. 315-330, 2001.

[210] R. Kridel, L. H. Sehn, and R. D. Gascoyne, "Pathogenesis of follicular lymphoma," The Journal of Clinical Investigation, vol. 122, no. 10, pp. 3424-3431, 2012. 


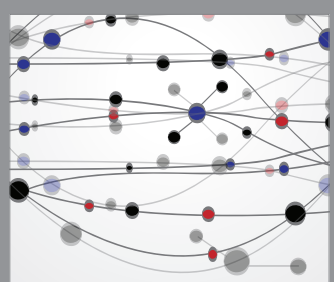

The Scientific World Journal
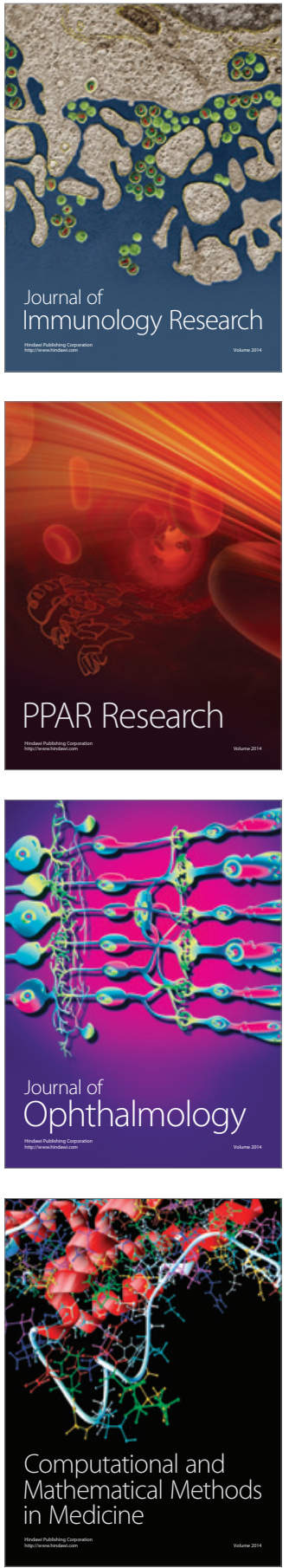

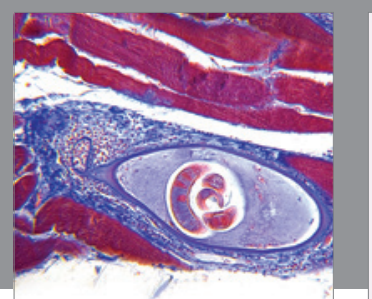

Gastroenterology Research and Practice

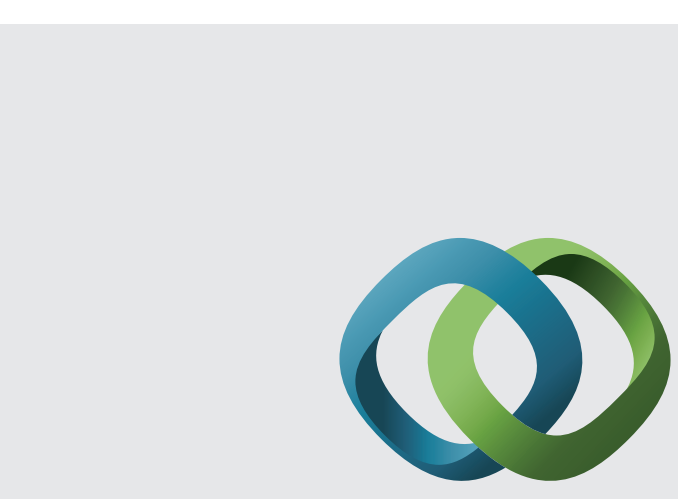

\section{Hindawi}

Submit your manuscripts at

http://www.hindawi.com
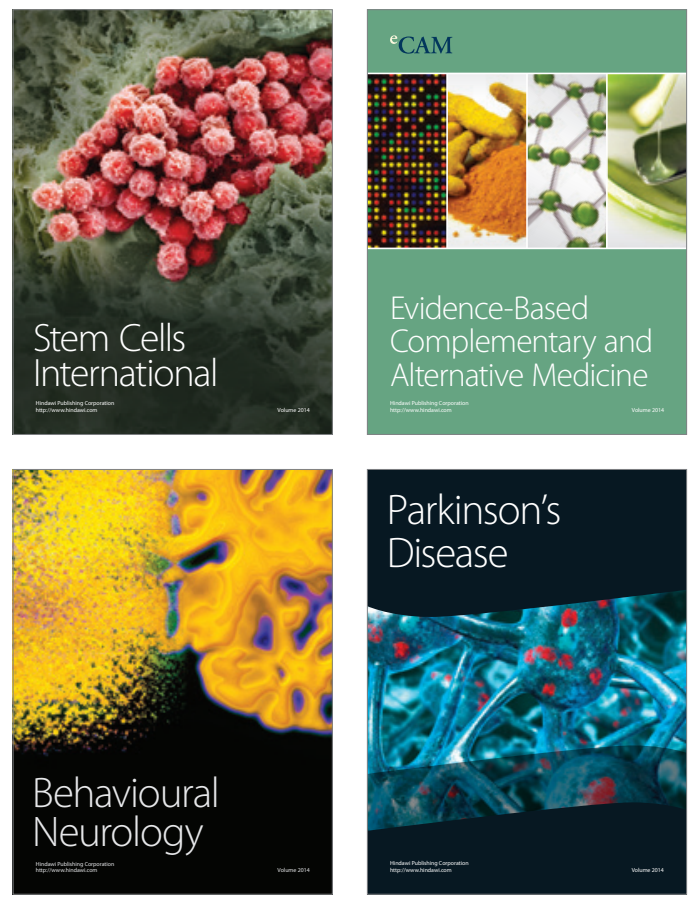
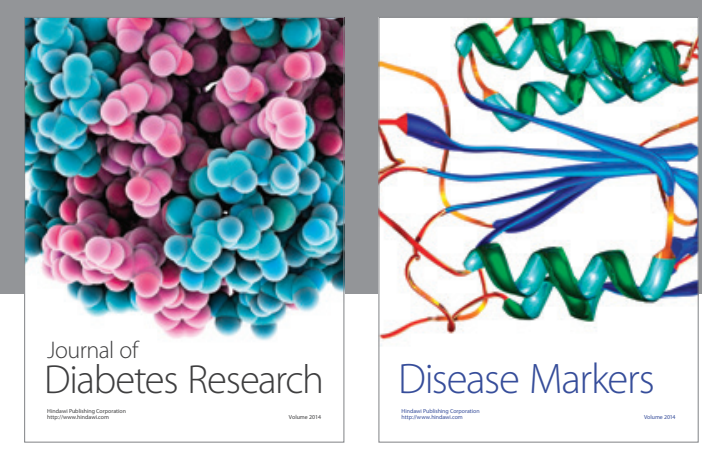

Disease Markers
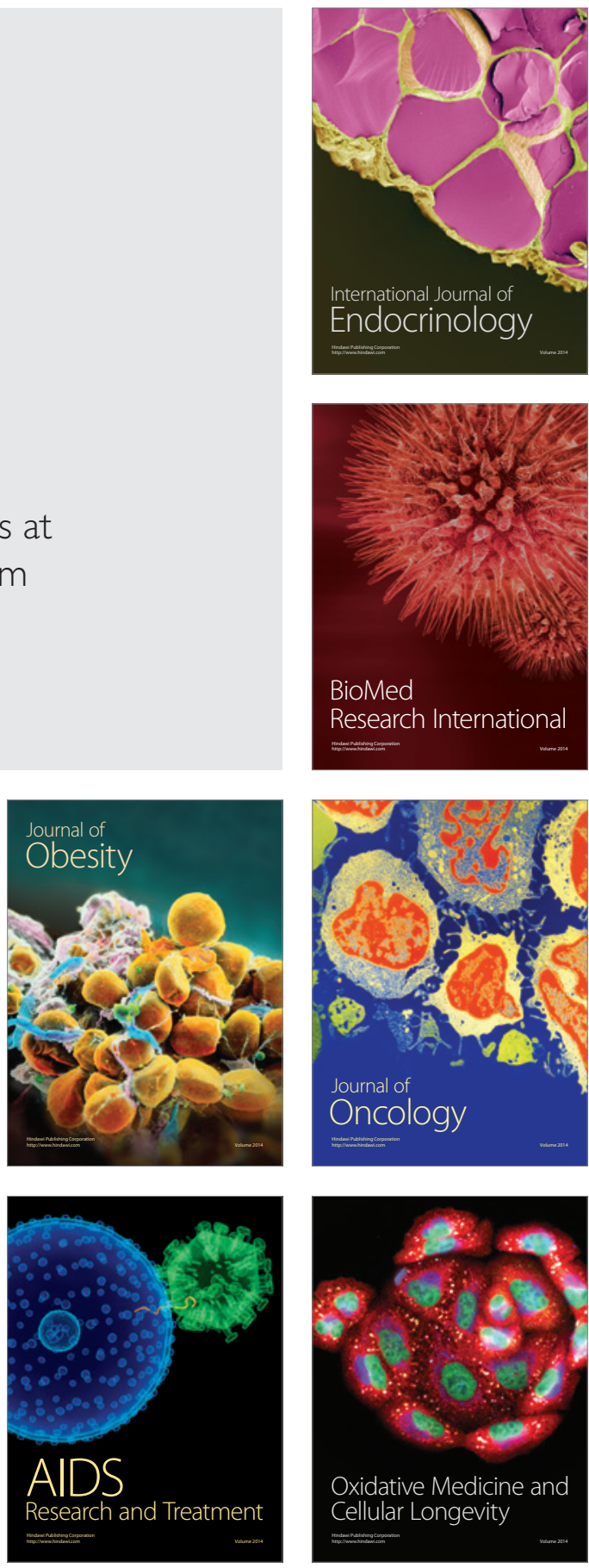